九州大学学術情報リポジトリ

Kyushu University Institutional Repository

Petrography of the Otozan Flow on Shodo-shima Island, Seto-uchi Inland Sea, Japan

Yamaguchi, Masaru

Faculty of Sciences, Kyushu University

https://doi.org/10.5109/1524312

出版情報：九州大學理學部紀要：Series D, Geology. 6 (3)，pp.217-238，1958-03-10. Faculty of Science, Kyushu University バージョン：

権利関係 : 
Mem. Fac. Sci., Kyushu Univ., Ser. D, Geology, Vol. VI, No. 3, pp. 217-238, text-figs. 1-14, tables 1-8, plates 36-40, March 1958

\title{
Petrography of the Otozan Flow on Shodo-shima Island, Seto-uchi Inland Sea, Japan*
}

By

\author{
Masaru Yamaguchi
}

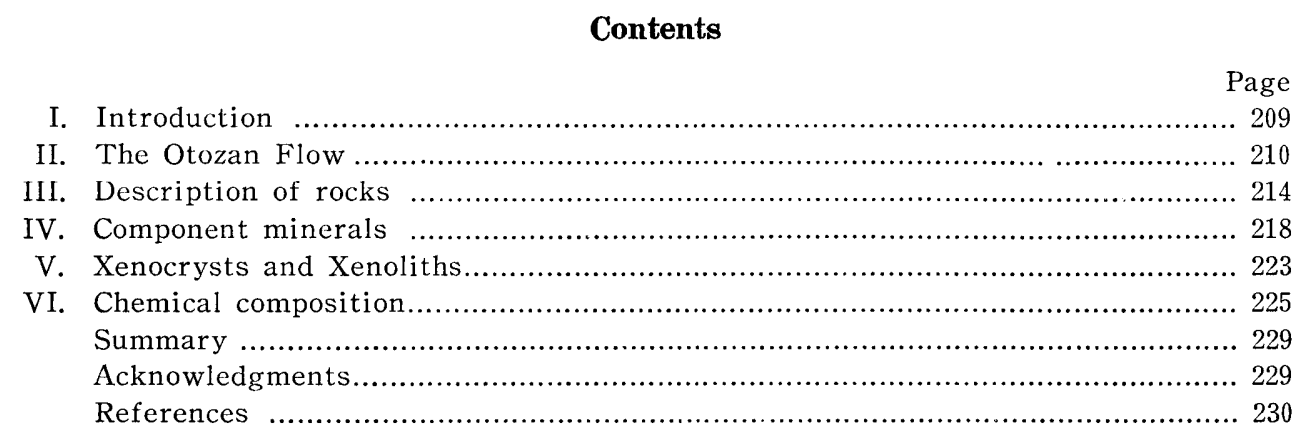

\section{Introduction}

"Sanukite", named by Weinschenk (1891) from Sanuki, the name of an old Japanese province in Shikoku of Southwest Japan, and the associated bronzite basalt-andesites (Кото's “sanukitoids,” 1916) have long been known as the characteristic rocks of the "Seto-uchi volcanic zone," which was active during late Tertiary. Geological and petrological importance of these rocks attracted attention of some workers to make preliminary but illuminating reports on them during last twenty years. Thus SATo $(1936,1938)$ made the first systematic investigation on the geology and petrography of Shodo-shima, an island in the Inland Sea (Seto-uchi or Seto-naikai) (Fig. 1), and the Takamatsu area, Shikoku. Mатuмото (1937) has noted that volcanic rocks in the Seto-uchi volcanic zone are distributed in groups at six areas about 120-160 kilometers apart from each other; namely, from east to

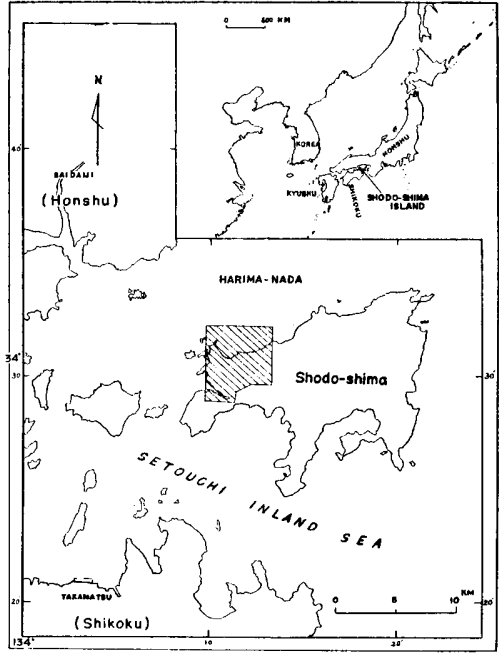

Fig. 1. Index map showing the location of the area described.

* Received October 15, 1957. 
west, the Shidara, Yamato, Sanuki, Ishiduchi, Ohno and Hizen areas along the Median Dislocation Line. Sugr (1938), examining the xenocrysts of quartz and plagioclase in the sanukites of the Takamatsu area, concluded that the rocks are formed from a hypothetical tholeiitic magma by assimilating granitic rocks. TAKeUCHI (1941) and KozU and YAGI (1941) regarded the phenocrysts of garnet (almandine-pyrope) in the biotite andesite from the Amataki Hill, Shikoku, as xenocrysts derived from micaschists at depth. The same view was taken by YosHizawa (1930), Ohmori (1942) and Morimoto (1944), on garnet in the biotite andesite from the Nijo volcano west of Nara city. Matsumoto (1950) has also accepted the view that there took place the contamination of an andesitic or olivine basaltic magma by granitic xenoliths in the volcanic rocks of the Takamatsu district. Tomira (1951) examined the petrochemistry of the Seto-uchi andesites and set forth the opinion that the contamination of olivine basalt magma is a matter of the first importance to the formation of these rocks. In this paper, the results of my petrographic studies of the Otozan Flow on Shodo-shima Island are given. It is a layered body composed of not a few differentiated rock types. As is generally known, the hypothesis of fractional crystallization in situ has been preferred to by most petrologists for explaining the formation of various rock facies within many layered igneous bodies not excluding effusive ones, yet in the case of the Otozan Flow the hypothesis finds no acceptance for the formation of the conspicuous variation in the rock types and structure. In my opinion, there are involved much more complicated processes which are related to hybridization and also to the mechanism of extrusion. The petrogenic problem not dealt with in this paper will be discussed in the near future.

\section{The Otozan Flow}

The Otozan Flow comprises the upper one-forth part of the Otozan Hill, 394 meters high, in Fuchizaki village on the western part of Shodo-shima Island. The geologic map of the Otozan area is shown in Fig. 2 and the stratigraphic succession of Shodo-shima in Fig. 3. The basement rocks are biotite semi-schist and hornfels (metamorphites from Permo-Carboniferous rocks), biotite granite (Lower Upper Cretaceous), and the Shikai Formation (Upper Oligocene or Lower Miocene). A flat erosion surface, 300 meters high, separates these rocks from the overlying Ikeda Member (Upper Miocene) which is composed of layers of medium sandstone, a lava sheet of olivine basalt, and layers of basaltic lapilli-tuff, tuff and breccia. The uppermost part, not more than fifteen meters in thickness, of the Ikeda Member which is composed of some layers of basaltic lapilli-tuff and breccia, grades gradually into the Otozan Flow, though at places the latter directly covers the underlying granite.

The Flow, 80-20 $\mathrm{m}$ in thickness, gently sloping and thinning towards the northeast, has the appearance of a narrow mesa bordered by bold cliffs (Fig. 4) with an exception on the north-east at Kasataki, where it is unconformably covered by layers of andesitic tuff and tuff breccia of the Omasan Member (Lower Pliocene). 


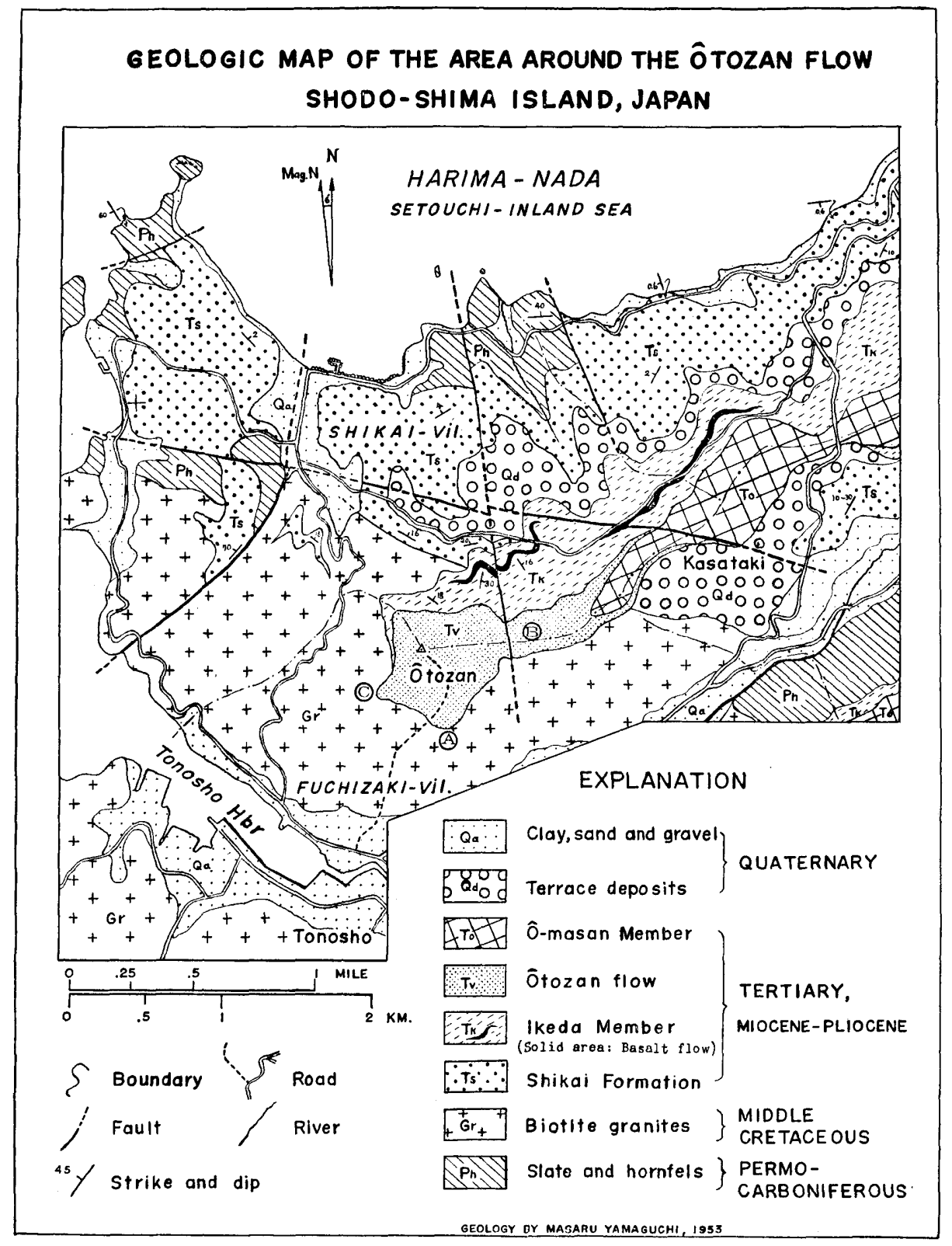

Fig. 2. Geologic map of the area around the Otozan Flow, Shodo-shima Island in the Seto-uchi Inland Sea, Japan. 


\begin{tabular}{|c|c|c|c|c|}
\hline \begin{tabular}{l|l}
$w$ & 0 \\
0 & \\
$<$ & 0
\end{tabular} & 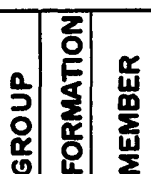 & 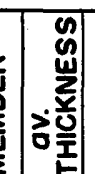 & $\begin{array}{r}\text { GEOLOGIC } \\
\text { COLUMN }\end{array}$ & LITHOLOGY \\
\hline
\end{tabular}

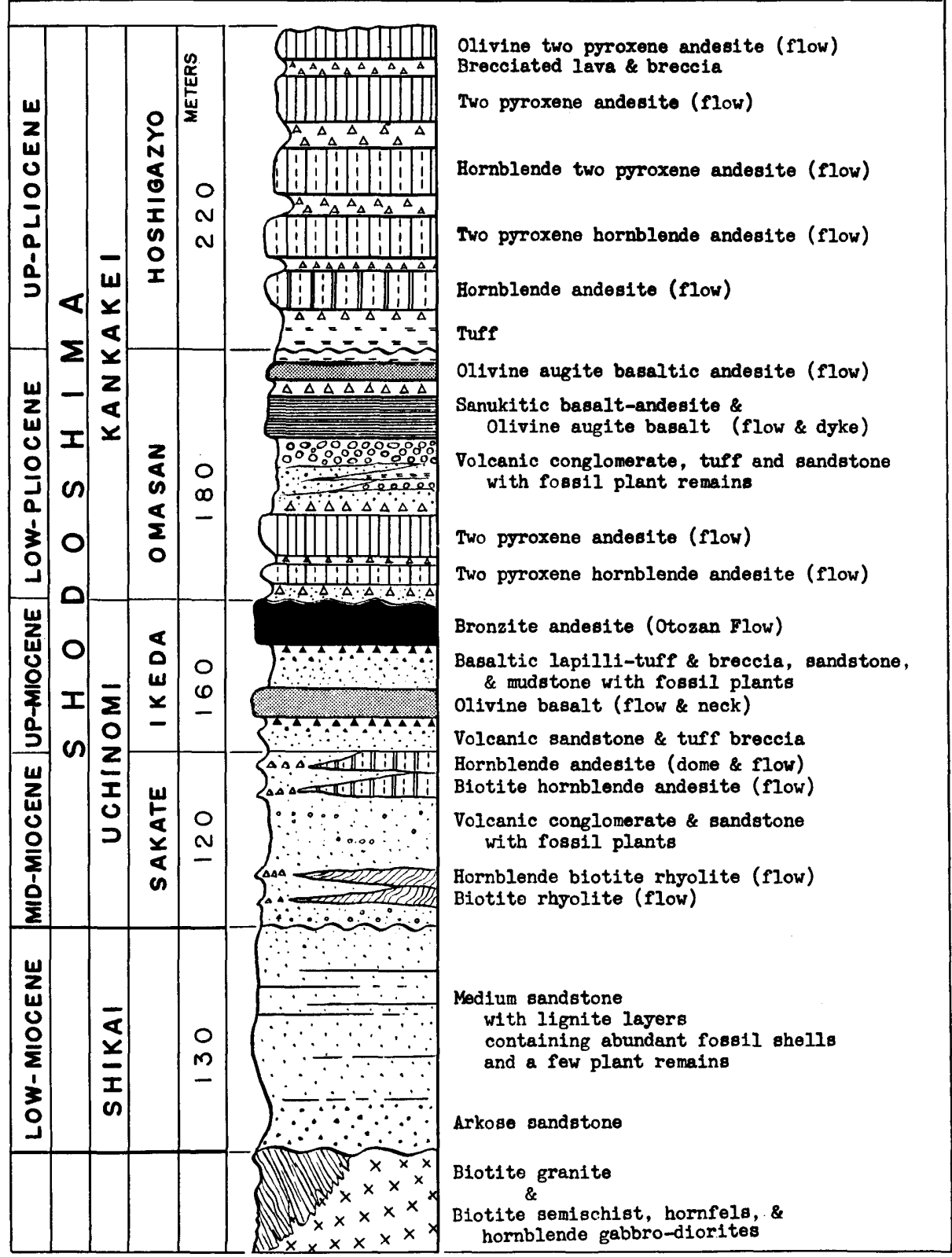

(Yamaguch1, 1957)

Fig. 3. Generalized geologic column of Shodo-shima Ișland. 


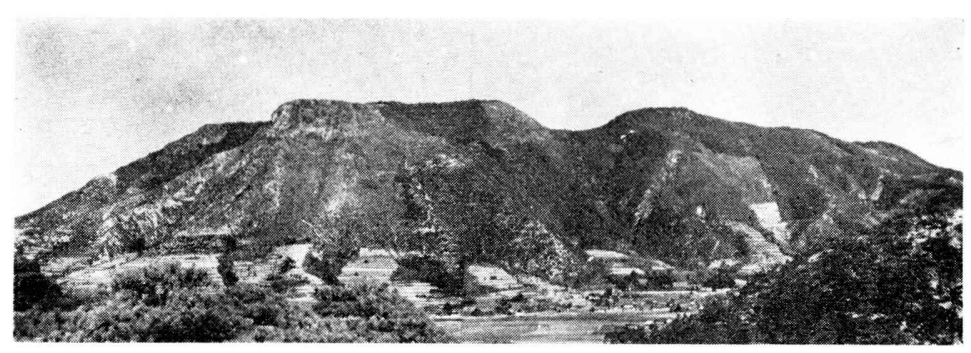

Fig. 4. Otozan Flow, Shodo-shima, seen from the east.

The rocks composing the Flow are compact and nearly aphanitic, rarely vesicular with elongated cavities, a few of which are filled with large crystals of brown calcite, zeolite and iron ores. In general, the lower part of the Flow is basaltic and the upper part andesitic, with a gradational transition irrespective of the thickness of the Flow.

The Flow is marked by distinctly layered structure due to different rock types and by regularly developed platy joints (Fig. 5). The structure, which is

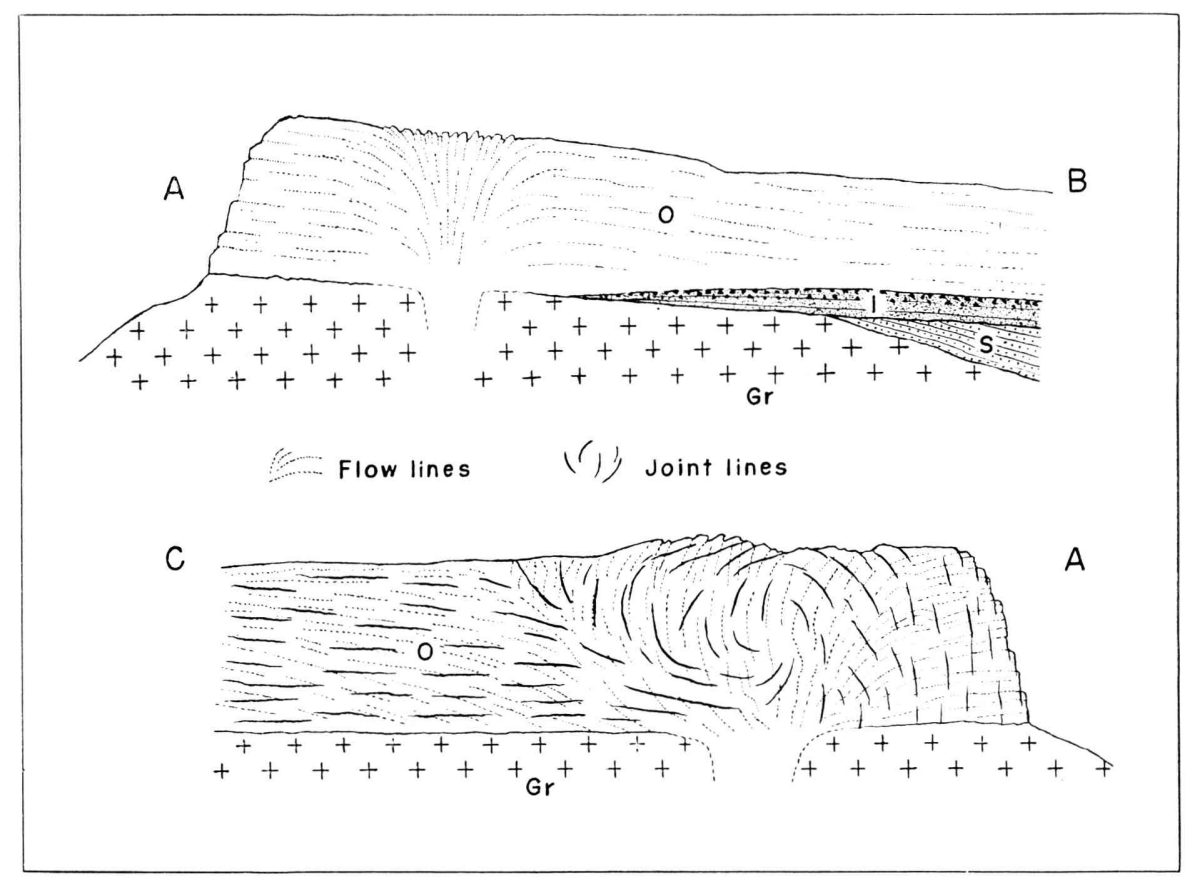

Fig. 5. Flow- and joint-lines of the Otozan Flow (Sections A-B, C-A refer to Fig. 2; O: Otozan Flow, I: Ikeda Member, S: Shikai Formation, Gr: Biotite granite).

prevailed throughout the whole flow except at the chilled margin (1-2 m thick), is readily recognizable by well-defined lamellae of fine pegmatitoids in parallel or subparallel arrangement with the microscopical flow planes which are particularly abundant in the middle and upper parts (Fig. 6). In the thickest part of the Flow 


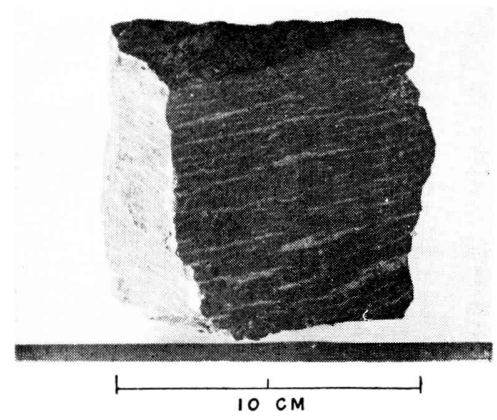

Fig. 6. Bronzite andesite from the middle part of the Otozan Flow with abundant fine streaks of pegmatitoid (white) elongated parallel to the flow planes. at the southeast end of the cliff, the structure is seen converging into a center, where the platy joints show a concentric structure. This center may possibly be the center of eruption (Fig. 5).

The variation in rock types which is shown by rock color (from the darker at the base to the lighter at the top), by mineralogical and chemical composition, and by specific gravity (Table 7) is quite distinct on the vertical section of the Flow, but not so along a flow plane. At the eruption center, where the flow planes are vertical, the rock types vary in the direction perpendicular to the flow planes from rather acid in the center to rather basic in the outer part, basaltic facies being lacking.

\section{Description of rocks}

\section{A. General characters}

It is very difficult to distinguish the individual flows composing the Otozan Flow, but the following four are distinguished as the main rock types (Fig. 7):

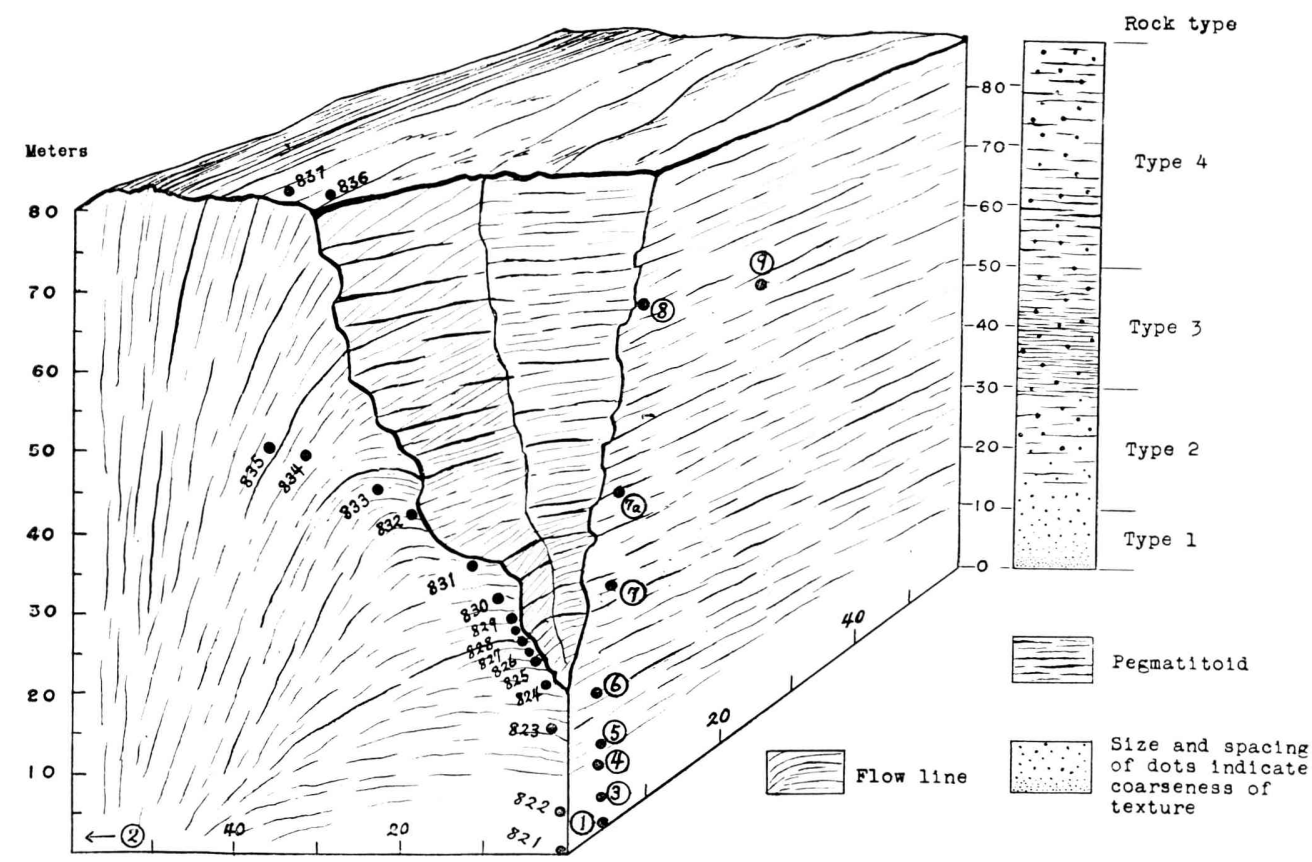

Fig. 7. Block diagram and columnar section of the Otozan Flow at the southern cliff (Point A in Fig. 2) showing respectively the flow structure and the lithologic variation. Dots and numbers indicate locations of specimens listed in Table 3 , figure in circle corresponds with the number of chemically analysed sample (Table 7 ). 


\begin{tabular}{|c|c|c|c|}
\hline & & Rock type & Maximum thickness \\
\hline Top & 4) & Bronzite andesite & ca. $30 \mathrm{~m}$. \\
\hline \multirow{2}{*}{ Intermediate } & 3) & Olivine-bronzite andesite & 20 \\
\hline & 2) & Augite-bearing olivine-bronzite andesite & 20 \\
\hline Base & 1) & Augite-olivine-bytownite andesitic basalt & 10 \\
\hline
\end{tabular}

(Sanukitic olivine basalt of SATo, 1936).

The general characteristics of each types are shown in Table 1, the composition of plagioclase together with the optical constant of other essential minerals in Table 2, and the microphotographs of these rocks in Plates 36 and 37.

Table 1. General characters of the rock types of the Otozan lavas.

\begin{tabular}{|c|c|c|}
\hline Rock type & $\begin{array}{l}\text { Megascopic } \\
\text { character }\end{array}$ & Microscopic character \\
\hline $\begin{array}{l}\text { Type } 4 \\
\text { Bronzite andesite } \\
\text { (Upper part) }\end{array}$ & $\begin{array}{l}\text { Light grey, compact, } \\
\text { aphyric, with fine } \\
\text { streaks of } \\
\text { pegmatitoid }\end{array}$ & $\begin{array}{l}\text { Slightly porphyritic, } \\
\text { Phenocrysts: bronzite, augite } \\
\text { (sporadic) } \\
\text { Groundmass: trachytic texture; } \\
\text { labradorite-andesine, } \\
\text { hypersthene, augite (a few), } \\
\text { magnetite, ilmenite, picotite, } \\
\text { phologopitic biotite (a few), } \\
\text { hornblende (rare), in the } \\
\text { mesostasis of potash-oligoclase, } \\
\text { alkali-feldspar, cristobalite }\end{array}$ \\
\hline $\begin{array}{c}\text { Type } 3 \\
\text { Olivine-bronzite andesite } \\
\text { (Upper intermediate part) }\end{array}$ & $\begin{array}{l}\text { Grey, compact, } \\
\text { aphyric, with } \\
\text { abundant fine } \\
\text { streaks of } \\
\text { pegmatitoid }\end{array}$ & $\begin{array}{l}\text { Slightly porphyritic, } \\
\text { Phenocrysts: bronzite, olivine, } \\
\text { augite (rare) } \\
\text { Groundmass: trachytic to } \\
\text { pilotaxitic texture; } \\
\text { labradorite, hypersthene, } \\
\text { augite, magnetite, ilmenite, } \\
\text { picotite, phologopitic biotite } \\
\text { (a few), hornblende (rare), in } \\
\text { the mesostasis of potash- } \\
\text { oligoclase, alkali-feldspar, } \\
\text { cristobalite (a few) }\end{array}$ \\
\hline $\begin{array}{l}\text { Type } 2 \\
\text { Augite-bearing olivine- } \\
\text { bronzite andesite } \\
\text { (Lower intermediate part) }\end{array}$ & $\begin{array}{l}\text { Grey to brown, } \\
\text { compact, aphyric }\end{array}$ & $\begin{array}{l}\text { Slightly porphyritic, } \\
\text { Phenocrysts: bronzite, olivine, } \\
\text { augite (a few) } \\
\text { Groundmass: trachytic to } \\
\text { pilotaxitic texture; } \\
\text { labradorite, hypersthene, } \\
\text { augite, magnetite, ilmenite, } \\
\text { picotite, in the mesostasis } \\
\text { of potash-oligoclase, } \\
\text { alkali-feldspar, cristobalite }\end{array}$ \\
\hline $\begin{array}{c}\text { Type } 1 \\
\text { Augite-olivine-bytownite } \\
\text { andesitic basalt } \\
\text { (Basal part: chilled margin, } \\
\text { about } 1-2 \text { meters thick) }\end{array}$ & $\begin{array}{l}\text { Dark grey or black, } \\
\text { compact, } \\
\text { slightly porphyritic } \\
\text { with olivines }\end{array}$ & $\begin{array}{l}\text { Slightly porphyritic, } \\
\text { Phenocrysts: olivine, augite, } \\
\text { bytownite } \\
\text { Groundmass: hyalopilitic to } \\
\text { pilotaxitic texture; } \\
\text { labradorite, augite, olivine } \\
\text { (rare) or hypersthene, magnetite, } \\
\text { ilmenite, picotite, in the } \\
\text { mesostasis of alkali-feldspar } \\
\text { and cristobalite or brown glass } \\
\text { with dusty iron ore in the } \\
\text { chilled phase }\end{array}$ \\
\hline
\end{tabular}


Table 2. Plagioclase composition and the optical constants of other essential minerals in the rock types of the Otozan Flow.

\begin{tabular}{|c|c|c|c|c|c|}
\hline \multicolumn{2}{|c|}{$\begin{array}{r}\text { Rock } \\
\text { Type }\end{array}$} & \multirow{2}{*}{$\begin{array}{c}\begin{array}{c}\text { Type } 1 \\
\text { Augite-olivine- } \\
\text { bytownite } \\
\text { andesitic basalt }\end{array} \\
\beta \fallingdotseq 1.665 \sim 1.695 \\
\text { mean } 1.680 \\
2 \mathrm{~V}=(+) 88^{\circ} \sim \\
(-) 80^{\circ}\end{array}$} & \multirow{2}{*}{$\begin{array}{c}\begin{array}{c}\text { Type } 2 \\
\text { Augite-bearing } \\
\text { olivine-bronzite } \\
\text { andesite }\end{array} \\
2 \mathrm{~V}=(+) 87^{\circ} \sim \\
(-) 75^{\circ}\end{array}$} & \multirow{2}{*}{$\begin{array}{c}\begin{array}{c}\text { Type } 3 \\
\text { Olivine-bronzite } \\
\text { andesite }\end{array} \\
\text { n.d. }\end{array}$} & \multirow{2}{*}{$\begin{array}{c}\text { Type } 4 \\
\text { Bronzite } \\
\text { andesite } \\
\text { none }\end{array}$} \\
\hline \multirow{4}{*}{ 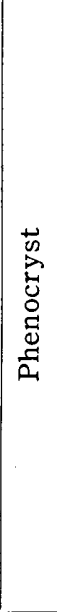 } & Olivine & & & & \\
\hline & Augite & $\begin{array}{l}\beta \fallingdotseq 1.685 \sim 1.689 \\
2 \mathrm{~V}=(+) 45^{\circ} \sim 52^{\circ}\end{array}$ & $\begin{array}{l}\beta=1.686 \sim 1.696 \\
2 \mathrm{~V}=52^{\circ} \sim 55^{\circ}\end{array}$ & $\begin{array}{l}\beta \fallingdotseq 1.698 \pm 0.002 \\
2 \mathrm{~V}=48^{\circ} \sim 50^{\circ}\end{array}$ & $\begin{array}{l}\text { n.d. } \\
\text { (very rare) }\end{array}$ \\
\hline & $\begin{array}{c}\text { Bronzite- } \\
\text { hyper- } \\
\text { sthene }\end{array}$ & none & $\begin{array}{l}2 \mathrm{~V} \text { range }=(+) \\
84 \sim(-) 64^{\circ} \\
2 \mathrm{Vmean}=(+) 87^{\circ} \\
\sim(-) 72^{\circ} \\
\text { (often oscilla- } \\
\text { tory or reversed } \\
\text { zoning) }\end{array}$ & $\begin{array}{l}\beta \doteqdot 1.674 \sim 1.694 \\
2 \mathrm{~V} \text { range }=(+) \\
82^{\circ} \sim(-) 62^{\circ} \\
2 \mathrm{~V} \text { mean }=(-) \\
82^{\circ} \sim(-) 70^{\circ} \\
\text { (often oscilla- } \\
\text { tory or reversed } \\
\text { zoning) }\end{array}$ & $\begin{array}{l}\beta \fallingdotseq 1.682 \sim 1.692 \\
2 \mathrm{~V} \text { range }=(+) \\
86^{\circ} \sim(-) 64^{\circ} \\
\left.2 \mathrm{~V} \text { mean } \fallingdotseq(-)^{\circ}\right)\end{array}$ \\
\hline & $\begin{array}{l}\text { Plagio- } \\
\text { clase }\end{array}$ & $\begin{array}{ll}\text { range } & 78 \sim 68^{\text {An } \%} \\
\text { mean } & 75 \sim 69\end{array}$ & $\begin{array}{l}\text { range } 78 \sim 60 \\
\text { mean } 74 \sim 64\end{array}$ & $\begin{array}{l}\text { range } 70 \sim 50 \\
\text { mean } 70 \sim 50 \\
\quad(\text { rare })\end{array}$ & $\begin{array}{l}\text { range } 64 \sim 44 \\
\text { mean } 63 \sim 44 \\
\quad(\text { very } \text { rare })\end{array}$ \\
\hline \multirow{7}{*}{ 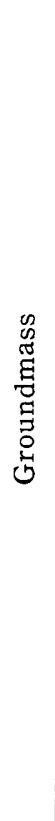 } & Olivine & $\begin{array}{c}2 \mathrm{~V}=(-) 84^{\circ} \sim \\
(-) 81^{\circ} \\
(\text { rare })\end{array}$ & none & none & none \\
\hline & Augite & $\begin{array}{l}\beta \doteq 1.676 \sim 1.681 \\
2 \mathrm{~V}=(+) 45^{\circ} \sim 48^{\circ}\end{array}$ & $2 \mathrm{~V}=48^{\circ} \sim 54^{\circ}$ & $2 \mathrm{~V}=52^{\circ} \pm$ & $2 \mathrm{~V}=50^{\circ} \pm$ \\
\hline & $\begin{array}{l}\text { Hyper- } \\
\text { sthene }\end{array}$ & $\begin{aligned} \beta \doteqdot & 1.680 \sim 1.686 \\
2 \mathrm{~V} & =(-) 75^{\circ} \sim \\
& (-) 67^{\circ} \\
& (\text { rare })\end{aligned}$ & $\begin{array}{r}2 \mathrm{~V}=(-) 73^{\circ} \sim \\
(-) 65^{\circ}\end{array}$ & $\begin{array}{r}2 \mathrm{~V}=(-) 72^{\circ} \sim \\
(-) 65^{\circ}\end{array}$ & $\begin{array}{c}\gamma \fallingdotseq 1.702 \pm 0.003 \\
2 \mathrm{~V}=(-) 70^{\circ} \widetilde{\sim} \\
(-) 62^{\circ}\end{array}$ \\
\hline & $\begin{array}{l}\text { Plagio- } \\
\text { clase }\end{array}$ & $\begin{array}{l}2 \mathrm{~V}=(+) 80 \sim 72, \\
\text { etc. } \\
\text { range } 75 \sim 45 \\
\text { mean } 74 \sim 60\end{array}$ & $\begin{array}{ll}\text { range } & 75 \sim 45^{\text {An } \%} \\
\text { mean } & 72 \sim 53\end{array}$ & $\begin{array}{ll}\text { range } & 65 \sim 45^{\text {An } \%} \\
\text { mean } & 63 \sim 48\end{array}$ & $\begin{array}{ll}\text { range } & 62 \sim 44 \\
\text { mean } & 60 \sim 45\end{array}$ \\
\hline & $\begin{array}{l}\text { Potash- } \\
\text { oligo- } \\
\text { clase }\end{array}$ & none & $\begin{array}{l}2 \mathrm{~V}=(+) 40^{\circ}, \\
50^{\circ}, 60^{\circ}\end{array}$ & $\begin{array}{l}2 \mathrm{~V}=(+) 35^{\circ} \\
40^{\circ}, 50^{\circ}, 60^{\circ}\end{array}$ & $\begin{array}{l}\alpha=1.534 \\
\beta=1.535 \\
2 \mathrm{~V}=(+) 40^{\circ} \\
50^{\circ}, 60^{\circ}\end{array}$ \\
\hline & $\begin{array}{l}\text { Alkali- } \\
\text { feldspar }\end{array}$ & n. d. & n. d. & $\begin{array}{l}\mathrm{n}<1.49 \\
2 \mathrm{~V}=(+) 80^{\circ} \pm \\
\quad(-) 70^{\circ} \pm\end{array}$ & $\begin{array}{l}2 \mathrm{~V}=(+) 84^{\circ} \sim \\
76^{\circ},(-) 83^{\circ} \sim 72^{\circ}\end{array}$ \\
\hline & Glass & $\mathrm{n}=1.489$ & n. d. & none & none \\
\hline
\end{tabular}




\section{B. Volumetric analyses}

Volumetric analyses of the phenocrysts in some specimens from various heights on the southeast cliff of the Flow (Fig. 7) were made with the results given in Table 3 and shown in Fig. 8. As is clearly seen in this Figure, an antipathetic relation between olivine and bronzite is remarkable.

Rough measurement of the groundmass minerals (Table 4) reveals that hypersthene, taking the place of the olivine which rarely occurs only at the basal part, increases gradually upwards while augite decreases. The amount of feldspathic

Table 3. Volume per cent of the mode of the Otozan lavas (Sample numbers refer to Fig. 7).

\begin{tabular}{|c|c|c|c|c|c|c|c|c|c|}
\hline Sample No. & 1 & 2 & 3 & 4 & 5 & 6 & 7 & 8 & 9 \\
\hline Groundmass & 90.7 & 91.8 & 93.5 & 93.6 & 93.3 & 95.2 & 94.6 & 94.3 & 93.8 \\
\hline Olivine & 5.3 & 4.8 & 1.2 & 1.1 & 0.0 & 0.0 & 0.0 & 0.0 & 0.0 \\
\hline $\begin{array}{l}\text { Serpentine after } \\
\text { olivine }\end{array}$ & 0.1 & 0.0 & 4.4 & 4.0 & 3.5 & 2.2 & 1.1 & 0.0 & 0.0 \\
\hline Augite & 1.6 & 1.6 & 0.4 & 0.5 & 0.4 & $\operatorname{tr}$ & 0.1 & 0.0 & 0.0 \\
\hline Bronzite & 0.0 & 0.0 & 0.0 & 0.0 & 1.0 & 2.4 & 3.8 & 5.4 & 5.9 \\
\hline Plagioclase & 2.2 & 1.6 & 0.3 & 0.1 & 0.5 & $\operatorname{tr}$ & 0.1 & 0.0 & 0.0 \\
\hline Xenocryst Pl. & 0.1 & 0.2 & 0.2 & 0.6 & 1.0 & 0.2 & 0.4 & 0.1 & 0.1 \\
\hline Xenocryst Q. & 0.0 & 0.0 & 0.0 & 0.1 & 0.3 & 0.0 & 0.0 & 0.2 & 0.2 \\
\hline \multicolumn{2}{|l|}{ Sample No. } & 821 & 822 & 823 & 824 & 825 & 826 & 827 & 828 \\
\hline \multicolumn{2}{|l|}{ Groundmass } & 92.6 & 92.3 & 93.2 & 93.9 & 94.6 & 92.7 & 94.2 & 96.4 \\
\hline & 5.3 & 3.2 & 1.5 & 0.6 & 0.9 & 0.2 & 0.0 & 0.0 \\
\hline \multicolumn{2}{|l|}{$\begin{array}{l}\text { Serpentine after } \\
\text { olivine }\end{array}$} & 0.0 & 2.9 & 4.0 & 3.5 & 4.0 & 2.8 & 4.0 & 2.0 \\
\hline \multicolumn{2}{|l|}{ Augite } & 1.1 & 0.7 & 1.0 & 1.8 & 0.3 & 2.6 & 0.3 & 0.0 \\
\hline \multicolumn{2}{|l|}{ Bronzite } & 0.0 & 0.0 & 0.0 & 0.0 & 0.0 & 1.7 & 1.1 & 1.2 \\
\hline \multicolumn{2}{|l|}{ Plagioclase } & 0.8 & 0.8 & 0.3 & 0.1 & 0.0 & 0.0 & 0.0 & 0.0 \\
\hline \multicolumn{2}{|l|}{ Xenocryst Pl. } & 0.2 & 0.1 & 0.0 & 0.1 & 0.1 & 0.0 & 0.2 & 0.4 \\
\hline \multicolumn{2}{|l|}{ Xenocryst Q. } & 0.0 & 0.0 & 0.0 & 0.0 & 0.1 & 0.0 & 0.2 & 0.0 \\
\hline \multicolumn{2}{|l|}{ Sample No. } & 829 & 830 & 831 & 832 & 833 & 834 & 835 & 837 \\
\hline \multicolumn{2}{|l|}{ Groundmass } & 96.0 & 97.6 & 96.4 & 96.3 & 94.1 & 94.9 & 95.4 & 94.4 \\
\hline \multicolumn{2}{|l|}{ Olivine } & 0.0 & 0.0 & 0.0 & 0.0 & 0.0 & 0.0 & 0.0 & 0.0 \\
\hline \multicolumn{2}{|l|}{$\begin{array}{l}\text { Serpentine after } \\
\text { olivine }\end{array}$} & 1.7 & 0.6 & 0.0 & 0.0 & 0.0 & 0.0 & 0.2 & 1.1 \\
\hline \multicolumn{2}{|l|}{ Augite } & $\operatorname{tr}$ & $\operatorname{tr}$ & $\operatorname{tr}$ & 0.1 & 0.3 & 0.4 & 0.1 & 1.6 \\
\hline \multicolumn{2}{|l|}{ Bronzite } & 1.9 & 1.6 & 2.9 & 3.6 & 5.5 & 4.6 & 4.3 & 2.8 \\
\hline \multicolumn{2}{|l|}{ Plagioclase } & 0.0 & $\operatorname{tr}$ & 0.0 & 0.0 & $0.0_{3}$ & $0.0_{3}$ & 0.0 & 0.1 \\
\hline \multicolumn{2}{|l|}{ Xenocryst Pl. } & 0.4 & 0.2 & 0.7 & 0.0 & 0.1 & 0.1 & 0.0 & 0.0 \\
\hline \multicolumn{2}{|l|}{ Xenocryst Q. } & 0.0 & 0.0 & 0.0 & 0.0 & 0.0 & 0.0 & 0.0 & 0.0 \\
\hline
\end{tabular}



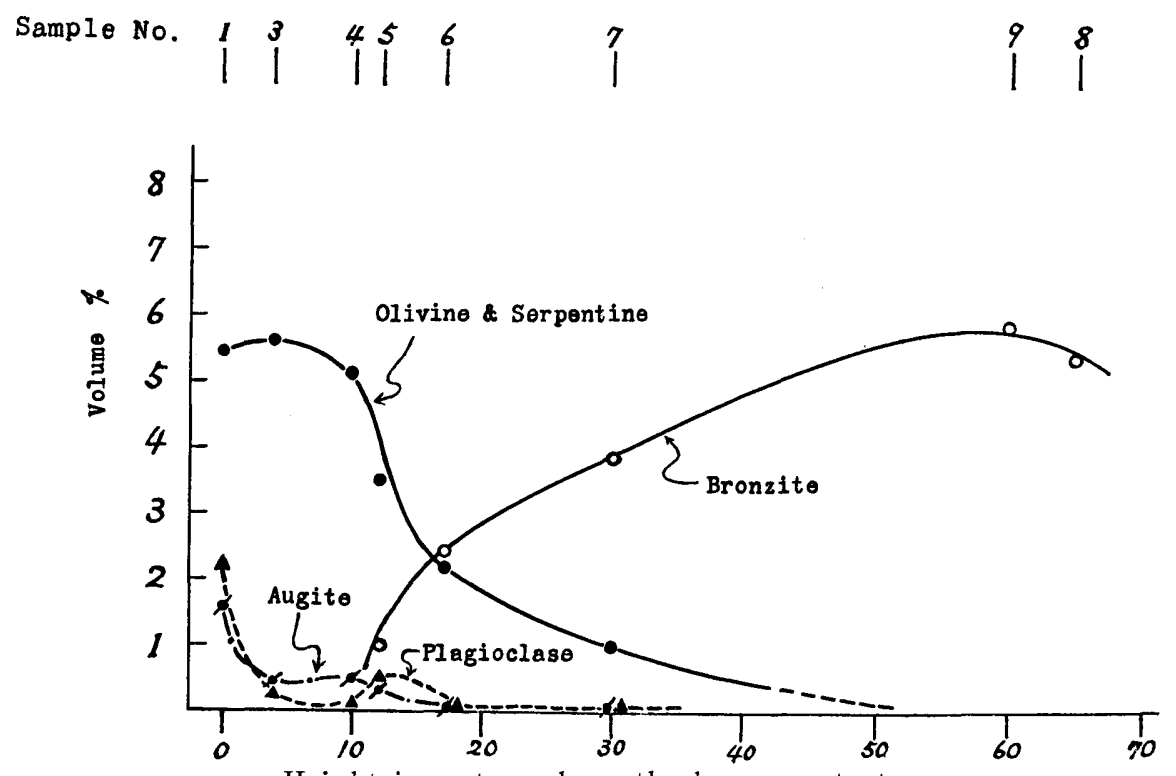

Height in meters above the lower contact

Fig. 8. Variation curve for the volumetric composition of phenocryst minerals against the height in the Otozan Flow.

Table 4. Volume per cent of the groundmass minerals of some Otozan lavas.

\begin{tabular}{l|r|r|r}
\hline \multicolumn{1}{c|}{ Sample No. } & 3 & 7 & 8 \\
\hline Augite & 19 & 8 & 4 \\
Hypersthene & 1 & 12 & 16 \\
Plagioclase. & 50 & 28 & 33 \\
Potash-oligoclase \& & 28 & 50 & 42 \\
$\quad$ Alkali-feldspar & 2 & 2 & 5 \\
\hline Iron ores & & & 5 \\
\hline
\end{tabular}

minerals (plagioclase plus potash-oligoclase plus alkali-feldspar) is constant throughout the Flow.

It should here be noted that the association and variation of the component minerals of the Otozan lavas are quite similar to those of the successive ejecta from Paricutin volcano in the period of 1943-1950 (Wiccox, 1954, p. 320).

\section{Component minerals}

\section{A. Olivine}

Phenocrysts of olivine are euhedral to subhedral, somewhat elongated or spindle shaped, and sometimes corroded. They are frequently altered partly or wholly to serpentine in the rocks of higher crystallinity composing the upper part of the Flow. Maximum size in section is $3 \times 1 \mathrm{~mm}$, commonly $1 \times 1 \mathrm{~mm}$. Olivine is zoned 
in its margin; most crystals are either optically positive or negative (2V over $\mathrm{X}$ is nearly $90^{\circ}$ ) at the core, while always optically negative in the margin. Their estimated composition (referring to Poldervaart's diagram, 1950) ranges in the different rock-facies from nearly Fo 88 to $F_{0} 63\left(2 \mathrm{~V}=(+) 87^{\circ}\right.$ to $\left.(-) 78^{\circ}\right)$, and that of different crystals within a single rock is greater at the basal chilled phase, where Fa-richer crystals are abundant, than the upper part.

Intergrowth of olivine and augite is observed in the lower lava and that of olivine and bronzite in the middle (Figs. $9 \mathrm{a}, \mathrm{b}, \mathrm{c})$. Olivine phenocrysts are usually surrounded by small grains of the groundmass augite and hypersthene, but those (richer in Fa content) in the chilled phase have no rim of pyroxene, being often rounded and embayed by magmatic resporption.

The groundmass olivine, which occurs only in the chilled phase, is as usual richer in $\mathrm{Fa}$ content than the phenocryst of the same rock.

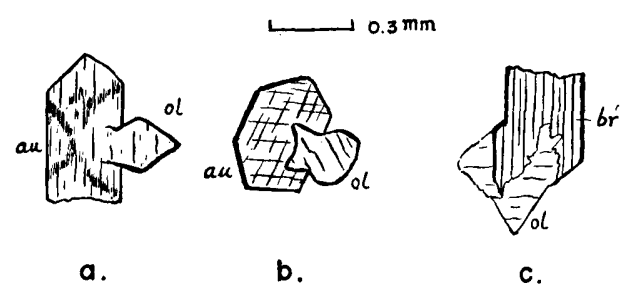

Fig. 9. Intergrowth of phenocrystic olivine (ol) and augite (au) or bronzite (br), a, b: olivine and strained augite; $c$ : serpentinized olivine and bronzite.

\section{B. Augite}

Phenocrysts of augite, about $0.5 \mathrm{~mm}$ in diameter, are euhedral, short prismatic, and often strained to show wavy extinction. They exhibit a mosoic appearance when observed with the universal stage. Twinning is rare, and zoning is not uncommon. (+) $2 \mathrm{~V}=45^{\circ}-52^{\circ}, \beta=1.685-1.698$.

The estimated composition (referring to the diagram of Hess, 1949) does not show wide variation within the Flow, but the augites of the upper facies is somewhat higher in Fs than those of the basal facies.

The groundmass augite grains, short prismatic, are, contrary to presupposition, poorer is Fs $\left(2 \mathrm{~V}=45^{\circ}-48^{\circ}, \beta=1.678\right)$ than the phenocrysts of the same rock. Moreover, they are commonly attached to the prism faces of bronzite-hypersthene, or found around quartz xenocrysts.

\section{Orthorhombic pyroxene}

Bronzite occurs as phenocrysts in the intermediate and upper parts of the Flow, rapidly increasing upwards in amount. Usually, they are long prismatic (the maximum length is about $5 \mathrm{~mm}$, commonly $1 \mathrm{~mm}$ ) with or without pyramidal faces; almost colorless to slightly colored with faint pleochroism. In general the mineral is normally zoned, the inner enstatite or bronzite being surrounded by a narrow rim of hypersthene. Within a single crystal the optic sign varies gradually from positive to negative outwards. The chemical composition (estimated from Kuno's diagram 1954) of the inner zone of bronzite phenocryst varies in 
average from about of 13 to of $18^{1}$, while that of the rim hypersthene from Of 25 to Of 30 , both slightly increasing in Of content upwards within the Flow.

However, reverse zoning, often oscillatory, is not rare, especially in the upper facies: the hypersthene core, pleochroic from pale green to pale pink, is followed by bronzite and then by hypersthene (Fig. 10). The estimated composition of the

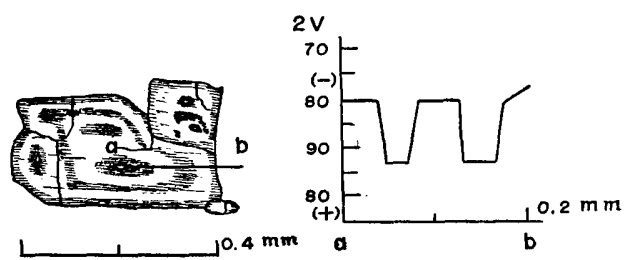

Fig. 10. Bronzite phenocryst and its mode of zoning with respect to the size of $2 \mathrm{~V}$. core is similar to the groundmass hypersthene or of the rim hypersthene. Sometimes, bronzite has a spot-like core of pleochroic hypersthene, which has pores and are often crowded with minute inclusions of iron ore. This core hypersthene may be a relict of xenocryst kept in bronzite.

Parallel intergrowth of phenocrystic bronzite and clinopyroxene is not un-

commmon. Thus, a thin layer of microphenocrystic augite grows on the bronzite, sometimes completely enveloping the latter. This intergrowth of pyroxene is rather common in the upper facies.

Groundmass orthopyroxene, ferrous bronzite or hypersthene, occurs in every rock facies, increasing upwards both in amount and in of content $\left((-) 2 \mathrm{~V}=75^{\circ}\right.$ to $\left.60^{\circ}\right)$. The composition however, varies even in a single groundmass, the widest range being of 25 to of 32 for a rock from the upper intermediate part of the Flow.

It is noteworthy that in the Otozan Flow occur sporadic xenocrysts of bronzite-hypersthene, some description of which will be given later.

\section{Plagioclase}

Phenocrysts of plagioclase are rather common in the lowest part of the Flow but they are rare in the middle and upper parts (Fig. 8).

They are usually idiomorphic tabular crystals, commonly about $1 \mathrm{~mm}$ in length. Twinning on the albite, Carlsbad, albite-Carlsbad, or pericline law, or even on the Manebach law is met with, but not complicated. Zoning is rather simple with calcic core and sodic margin; the widest range in composition of a single crystal does not exceed 20 per cent of An content. The average composition indicates that phenocrystic plagioclase is bytownite in the lower facies and labradorite to andesine in the upper facies.

As to the groundmass plagioclase (An 75-An 45), there are two types of occurrence: one is a lath-shaped microlite and the other is a thick tabular subhedral crystal. The latter shows fine lamellae of polysynthetic albite twinning, rather simple zoning with variant optic angles ranging from about $(-) 84^{\circ}$ to $75^{\circ}$, and

1) The widest range for the bronzite in a single specimen of the olivine-bronzite andesite from the upper intermediate part is of 8 to of 32 . 
undulate extinction; ${ }^{1)}$ it has cracks filled with a highly double-refracting greenish mineral.

The composition of groundmass plagioclase in each rock type shows a wide variation due to zoning, the widest range being about 30 per cent in An content for the rock of the lower part. Thus the core is most calcic in the lower facies and more sodic in the upper facies, while the outermost margin does not show any notable difference between the lower and the upper facies.

\section{E. Potash-plagioclase}

This mineral is entirely confined to the interstices of the groundmass and is present in relatively greater amount in the more highly crystalline bronzite andesite of the middle and upper parts of the Flow, but is generally absent in the lavas with glass mesostasis (chilled phase). Occurring interstitially, this mineral encloses on one hand plagioclase, hypersthene, iron ore and apatite, of which abundant minute crystals of the apatite of highly acicular habit are highly remarked, and is on the other hand closely associated with alkali-feldspar and cristobalite. The occurrence just mentioned confirms that this mineral is the latest product of crystallization probably parallel with the alkali-feldspar and cristobalite.

It is rather tabular, anhedral to subhedral, and untwinned. Poor cleavage is sometimes observed. The extinction is frequently irregular or undulatory. The refringence and birefringence are low and the optic angle is small with a positive sign (P1. 38, Fig. 9).

Table 5. Optical constants of potash-rich plagioclase in the groundmass of volcanic rocks.

\begin{tabular}{|c|c|c|c|c|c|c|c|}
\hline No. & Name & $\underset{\text { (estimated) }}{\text { Or Ab An }}$ & $\alpha$ & $\beta$ & $\gamma$ & $2 \mathrm{~V}$ & Locality \\
\hline 1. & Potash-andesine & $\begin{array}{lll}11 & 46 & 43\end{array}$ & 1.550 & 1.551 & & $(+) 48^{\circ}$ & Dogo, Oki, Japan \\
\hline 2. & Potash-andesine & none & & $\begin{array}{l}1.541- \\
1.554\end{array}$ & & $(+) 44^{\circ}-48^{\circ}$ & , \\
\hline 3. & Potash-andesine & $12 \quad 54 \quad 34$ & & 1.536 & & $(+) 43^{\circ}$ & $\begin{array}{l}\text { Hsueh-hua-shan Hill, } \\
\text { North China }\end{array}$ \\
\hline 4. & Potash-oligoclase & none & 1.545 & 1.547 & 1.550 & (十) $40^{\circ}-60^{\circ}$ & Hawaiian Islands \\
\hline 5. & Potash-oligoclase & none & 1. 534 & 1.535 & & $(+) 40^{\circ}-60^{\circ}$ & $\begin{array}{l}\text { Otozan Flow, } \\
\text { Shodo-shima, Japan }\end{array}$ \\
\hline
\end{tabular}

1. TомгтA, T. (1948) Kagaku Jiho, p. 91-93 (in Chinese).

- (1935) J. Shanghai Sci, Inst., Sec. II, Vol. 1, No. 12, 272.

- (1931) Jour. Geol. Soc. Japan, 38, 426, etc.

2. - (1931) Jour. Geol. Soc. Japan, 38, 546, etc.

3. - - (1948) Kagaku Jiho, p. 91-93 (in Chinese).

4. Macdonald, G. A. (1942) Am. Mineral., 27, 793-800.

5. Yamaguchi, M., this paper.

1) The undulate extinction seems to be seen when the mineral is cut obliquely at a small angle to the twinning plane. 
Optical properties of this mineral from the bronzite andesite (P1. 39, Fig. 10) in the upper lava are:

$$
\begin{aligned}
& Z \text { nearly normal to cleavage plane } \\
& \mathrm{n}_{1} \fallingdotseq \alpha=1.534 \\
& \mathrm{n}_{2} \doteqdot \beta=1.535 \\
& \text { (t) } 2 \mathrm{~V}=60^{\circ}, 50^{\circ}, 40^{\circ}
\end{aligned}
$$

The positive optic angle varies in different crystals in the same thin section within a range of 20 or more, the range of the variation in different rock types being as much (Table 2). For comparison, the optical data for the known anomalous plagioclase similar to the Otozan mineral are listed in Table 5. Tomita's "potash-andesine" $(1931,1935,1948)$ in the basaltic lavas of the Circum Japan Sea region and the adjacenet land of the East Asiatic Continent may be, according to him, a metastable form of potash-rich plagioclase and forms a probable discontinuous reaction series with anorthoclase and sanidine, the potash feldspar molecules of the mineral is considered by him to be responsible for lowering both the optic angle and the refractive indices. Having re-examined BArth's "anemousite" (1930) in the Hawaiian lavas, Macdonald (1942) has agreed with Tomita's view and he, following Tомгта's nomenclature, renamed it "potash-oligoclase."

In the case of the Otozan lavas, both orthoclase and albite components of the normative feldspar is always in excess of the modal plagioclase of the same rock. This excess is most probably accounted for by the presence of the mineral in question and a little alkali-feldspar in the groundmass.

11.

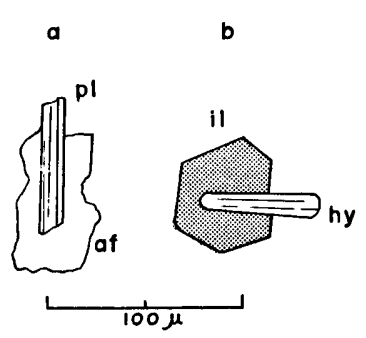

Fig. 11. Mutual relationships between andesine (pl) and alkali-feldspar (af), and between hypersthene (hy) and ilmenite (i1) in the groundmass.

\section{F. Alkali-feldspar}

Alkali-feldspar is occasionally found in the interspaces. of the groundamss (smaller in amount in the lower facies), closely associated with potash-oligoclase, enclosing plagioclase microlite and other early crystallized minerals except apatite (Fig. 11a). It is commonly unhedral, fine crystal and sometimes stained brown.

\section{G. Accessory minerals}

1, Amphibole: Microlites of light greenish amphibole $\left(c^{\wedge} Z=15^{\circ}\right)$ with weak pleochroism are rarely met with in the groundmass of the upper facies.

2. Biotite: Phologopitic biotite occurs as flakes and frequent fringes around the microlites of bronzite and hypersthene in the groundmass, closely associating with crystals of hornblende. It is abundant in the pegmatitoids. The optical properties are:

(-) $2 \mathrm{E}=20^{\circ}, \beta=1.564$ with strong pleochroism: $\mathrm{X}=$ pale brown or almost colorless, $\mathrm{Y}=$ greenish brown, $\mathrm{Z}=$ yellowish brown, absorption $\mathrm{X}<\mathrm{Z} \leqslant \mathrm{Y}$. 
3. Quartz and cristobalite: Quartz occurs as xenocrysts as described later.

Cristobalite, commonly occuring interstitially closely associated with biotite and alkali-feldspar, is usually spread sporadically in the groundmass, but it is particularly abundant within the pegmatitoids in the intermediate and upper facies.

4. Ilmenite, picotite, magnetite and hematite: These minerals occur only in the groundmass. Ilmenite, greenish brown to reddish brown, translucent or turbid, appears in the groundmass of high crystallinity as irregular flakes or grains, often attached to the margin of bronzite or hypersthene, but sometimes as separated hexagonal plates which partly enclose hypersthene (Fig. $11 \mathrm{~b}$ ).

Picotite, light brown to reddish brown in color, occurs either as small octahedral particles enclosed in olivine phenocrysts or as isolated grains in the groundmass. The rather high $\mathrm{Cr}_{2} \mathrm{O}_{3}$ content of the Flow amounting to about 0.04 per cent for basic calc-alkaline volcanic rocks may be due partly, if not wholly, to the abundance of this mineral.

Minute particles abundantly enclosed in the brown glass or the bronzite phenocryst are identified by their color displayed by reflected light as magnetite, ilmenite and hematite, some larger grains being composed commonly of magnetite and hematite. Though they appear as rather rounded irregular grains in the rock slices of standard thickness, on the polished surface under high magnification they always reveals themselves as euhedral crystals.

\section{H. Minerals of pegmatitoid}

Abundant fine pegmatitic streaks (pegmatitoids) in which are developed though rarely some small cavities are always seen running parallel to the flow planes of the middle and upper lavas in the Flow (Fig. 6). Rock with these pegmatitoids can easily be split itself along them. Any veinlet, supposed feeder of the pegmatitoid, cannot be observed within the Flow.

The pegmatitoid consists generally of cristobalite, alkali-feldspar and biotite. Sometimes, occurs interstitially a highly double-refracting greenish mineral, which may be identical with the already mentioned mineral filling the cracks in plagioclase. The pegmatitic part grades gradually into the compact part of the groundmass, although there is a marked difference in the mineralogical composition and the degree of crystallinity between the two.

\section{Xenocrysts and xenoliths}

\section{A. Usual xenocrysts and xenoliths}

Sporadic xenocrysts of plagioclase and quartz are detected in the Otozan Flow. Their total amount is not more than one per cent of the rock.

1. Plagioclase: Xenocrysts of plagioclase (Pl. 40, Fig. 13) are readily distinguishable from the phenocrysts by their larger size, irregular shape, fine lamellae 
Table 6. Estimated composition of xenocrystic and groundmass plagioclases of the Otozan Flow.

\begin{tabular}{|c|c|c|c|}
\hline \multicolumn{2}{|c|}{ Xenocrystic plagioclase } & \multicolumn{2}{|c|}{ Groundmass plagioclase } \\
\hline Core & Reaction rim & Range & Mean range \\
\hline An\% & An $\%$ & An $\%$ & An\% \\
\hline \begin{tabular}{l|l}
39 & aggregate \\
35 &
\end{tabular} & $61 \sim 45$ & $61 \sim 45$ & $60 \sim 45$ \\
\hline 45 & $49 \sim 45$ & $65 \sim 45$ & $63 \sim 48$ \\
\hline $\left.\begin{array}{l}42 \\
45 \\
50\end{array}\right\}$ & $\left.\begin{array}{l}68 \sim 50 \\
68 \sim 48 \\
68 \sim 49\end{array}\right\}$ & $75 \sim 45$ & $73 \sim 56$ \\
\hline 46 & no rim & $75 \sim 60$ & $74 \sim 66$ \\
\hline
\end{tabular}

of polysynthetic twinning, most sodic cores (An 35-50) with clear calcic rims (An 68-45), and by honeycombed structure due to partial vitrification caused by magmatic heating. The clear rim is very narrow or sometimes faint, and no intense corrosin is observed. The composition of the rim is in general nearly equal to, or slightly sodic than, the groundmass plagioclase in the same rock (Table 6).

2. Quartz: Xenocrysts of quartz are usually irregular in shape and surrounded by a corona consisting mainly of augite grains which are optically similar to the groundmass augite, of ten accompanied by cristobalite, alkali-feldspar and phologopitic biotite (Fig. 12), and rarely by several small grains of hornblende.

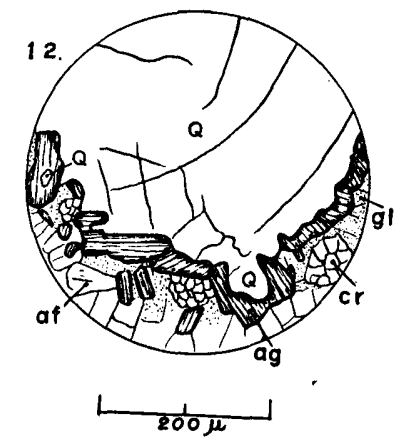

Fig. 12. Quartz xenocryst (Q) surrounded by an aggregate consisting of augite (ag), glass ( $\mathrm{gl})$, cristobalite (cr), and alkali-feldspar (af).

3. Xenolith: Xenolithic fragments are sporadically present. Some of them are mosaic aggregates of quartz, or both quartz and iron ores, surrounded by a corona of pyroxene (Pl. 40, Fig. 14). Sometimes, there occur aggregates of prismatic augite and bronzite embracing biotite and alkali-fedspar in their center. They seem to represent the advanced stage of the interaction between quartz xenolith and liquid magma; for reference, two advanced stages of the transformation phase of some xenoliths are shown in Plate 40, Figs. 15 and 16.

The origin of the above-mentioned xenocrysts and xenoliths is not certain, but the petrographic characters of these foreign materials and the geology of the area concerned suggest that most of them may have been derived from deep-seated rocks. On the other hand, occasional fragments of granite and sediments which closely resemble the basement rocks are found enclosed in the basal part of the Flow, but they show little thermal effect. This latter kind of xenoliths may have been derived not from the deeper part of the crust, but from the near-surface vent walls, having been allowed no ample heat and no sufficient time for the thermal effect of the magma. 


\section{B. Orthopyroxene of unusual structure}

In the bronzite andesite are rarely met with sporadic orthopyroxene of unusual structure, occuring as a single crystal or an aggregate of two or three. Generally speaking, it is distinctly larger in size than the phenocrystic orthopyroxene. This orthopyroxene falls into two kinds: one is of a cage-like structure with some feldspathic minerals in the center (Pl. 39, Fig. 11), and the other is of a sieve structure with many pores filled with feldspathic mineral and/or glassy material with brownish dusty ores. The former shows (-) $2 \mathrm{~V}=80^{\circ}-85^{\circ}$ (En 82-En 85), and the latter (-) $2 \mathrm{~V}=65^{\circ}$ (En 68) in the center and (-) $2 \mathrm{~V}=85^{\circ}-65^{\circ}$ (En 85-En 68) at the rim (Pl. 39, Fig. 12). These values are not so different from those of the phenocrysts.

Although no comprehensive explanation for the origin of such bronzitehypersthene of unusual appearance can now be given because of scanty examination, it is natural to say that they should be "grown xenocrysts"-by this is meant that they are originally some xenocrystic ferromagnesian materials which have later been transformed and grown by magmatic reaction to the present state.

\section{Chemical composition}

Chemical analyses were made on ten specimens, nine of which were used for the measurement of modal composition (Table 3,4). The chemical composition and norms, and the ratios norm or-ab-an, Q-fo-fa (Tомтт, 1951) and MgO-FeOAlkalies of the Otozan Flow along with one analysis (No. 10) of "sanukite" from SANUKI (TRÖGER, 1935, p. 163) are given in Table 7, and the chemical variations against the height and silica content are shown in Figs. 13 and 14, respectively. The estimated groundmass compositions selected from each rock type (Nos. 1, 2, 4,7 and 8 ) are also given in Table 8.

The alkali-lime index for the Otozan Flow is about 59.2. Though this value is approximately equal to that of the calc-alkalic suite of the San Juan region (59.4; BARTh, 1952, p. 171) or the Normal Magma Series of Mull (59.8; BaIley et al., 1924, p. 13-39), the Flow shows a striking peculiarity in that magnesia and the alkalies, especially potash, are richer and ferri-ferrous iron is poorer than many other volcanic rocks in Japan and other countries. As already referred to, this peculiarity of the Flow is due without doubt to the particular abundance of bronzite and the very presence of potash-oligoclase. 
Table 7. Chemical analyses of Otozan lavas from the southern cliff (Nos. 1-9) and sanukite of Sanuki, Shikoku (No. 10).

\begin{tabular}{|c|c|c|c|c|c|c|c|c|c|c|c|}
\hline Sample No. & 1 & 2 & 3 & 4 & 5 & 6 & 7 & $7 \mathrm{a}$ & 8 & 9 & 10 \\
\hline $\begin{array}{l}\mathrm{SiO}_{2} \\
\mathrm{Al}_{2} \mathrm{O}_{3} \\
\mathrm{Fe}_{2} \mathrm{O}_{3} \\
\mathrm{FeO} \\
\mathrm{MgO} \\
\mathrm{CaO} \\
\mathrm{Na}_{2} \mathrm{O} \\
\mathrm{K}_{2} \mathrm{O} \\
\mathrm{H}_{2} \mathrm{O}(+) \\
\mathrm{H}_{2} \mathrm{O}(-) \\
\mathrm{TiO}_{2} \\
\mathrm{P}_{2} \mathrm{O}_{5} \\
\mathrm{MnO} \mathrm{NiO}^{*} \\
\mathrm{Cr}_{2} \mathrm{O}_{3} * \\
\mathrm{~V}_{2} \mathrm{O}_{3} * \\
\mathrm{CuO}^{*} \\
\mathrm{ZnO}^{*} \\
\mathrm{CoO}^{*}\end{array}$ & $\begin{array}{l}57.59 \\
16.70 \\
1.56 \\
4.18 \\
6.53 \\
7.01 \\
3.44 \\
1.82 \\
0.10 \\
0.60 \\
0.88 \\
0.17 \\
0.08 \\
0.015 \\
0.013 \\
0.0013 \\
0.0118 \\
0.0013\end{array}$ & \begin{tabular}{|c|}
57.68 \\
17.73 \\
1.56 \\
4.10 \\
6.18 \\
6.41 \\
3.29 \\
1.54 \\
0.62 \\
0.40 \\
0.56 \\
0.16 \\
0.12 \\
0.02 \\
0.045 \\
0.013 \\
0.0015 \\
0.0110 \\
0.0016
\end{tabular} & $\begin{array}{c}57.11 \\
17.58 \\
2.16 \\
3.32 \\
6.10 \\
6.51 \\
3.64 \\
1.72 \\
0.53 \\
0.47 \\
0.54 \\
0.18 \\
0.12 \\
0.023 \\
0.012 \\
0.0015 \\
0.0124 \\
0.0016\end{array}$ & \begin{tabular}{|c|}
58.18 \\
17.81 \\
2.07 \\
2.98 \\
6.08 \\
6.06 \\
3.32 \\
1.84 \\
0.56 \\
0.73 \\
0.54 \\
0.17 \\
0.12 \\
0.019 \\
0.013 \\
- \\
0.0014
\end{tabular} & $\begin{array}{r}58.83 \\
17.66 \\
2.19 \\
2.77 \\
5.46 \\
5.19 \\
3.57 \\
1.85 \\
0.92 \\
0.78 \\
0.46 \\
0.16 \\
0.06 \\
= \\
= \\
= \\
-\end{array}$ & 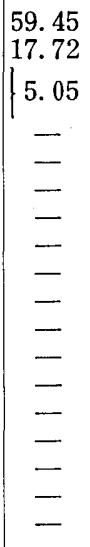 & \begin{tabular}{|l|}
60.77 \\
17.58 \\
1.68 \\
2.32 \\
4.59 \\
4.90 \\
4.13 \\
1.76 \\
0.68 \\
0.76 \\
0.51 \\
0.18 \\
0.11 \\
0.017 \\
0.033 \\
0.012 \\
- \\
0.0014
\end{tabular} & $\begin{array}{l}61.32 \\
17.52 \\
4.25 \\
= \\
= \\
= \\
= \\
= \\
= \\
= \\
= \\
= \\
=\end{array}$ & $\begin{array}{l}61.29 \\
17.24 \\
1.86 \\
2.68 \\
4.33 \\
5.21 \\
4.15 \\
1.79 \\
0.72 \\
0.65 \\
0.46 \\
0.14 \\
0.11 \\
0.019 \\
0.012 \\
- \\
0.0027\end{array}$ & \begin{tabular}{|c|}
62.24 \\
17.36 \\
1.99 \\
2.48 \\
4.24 \\
5.05 \\
4.11 \\
1.83 \\
0.25 \\
0.40 \\
0.56 \\
0.12 \\
0.12 \\
0.019 \\
0.011 \\
- \\
0.0011
\end{tabular} & $\begin{array}{r}63.93 \\
16.46 \\
2.45 \\
2.35 \\
2.58 \\
4.66 \\
4.15 \\
2.71 \\
0.15 \\
0.00 \\
0.50 \\
0.10 \\
0.18 \\
= \\
= \\
= \\
=\end{array}$ \\
\hline Total & 100.66 & 100.35 & 99.98 & 100.46 & 99.90 & - & 99.97 & - & 100.63 & 100.75 & $100.43^{* *}$ \\
\hline Sp. Gr. $d_{4}{ }^{10}$ & 2.78 & 2. 72 & 2.71 & 2.71 & 2.68 & 2.69 & 2. 71 & - & 2. 65 & 2. 63 & 2.57 \\
\hline $\begin{array}{l}\text { Q } \\
\text { C } \\
\text { or } \\
\text { ab } \\
\text { an } \\
\text { wo } \\
\text { en } \\
\text { fs } \\
\text { mt } \\
\text { il } \\
\text { ap }\end{array}$ & $\begin{array}{r}6.20 \\
-\overline{10.57} \\
28.84 \\
25.03 \\
3.68 \\
16.29 \\
5.01 \\
2.32 \\
1.67 \\
0.33\end{array}$ & $\begin{array}{r}8.31 \\
-\overline{8} \\
27.70 \\
29.19 \\
0.31 \\
15.48 \\
5.54 \\
2.09 \\
1.06 \\
0.33\end{array}$ & $\begin{array}{r}6.14 \\
10.02 \\
30.93 \\
26.69 \\
1.94 \\
16.28 \\
3.43 \\
3.25 \\
1.06 \\
0.33\end{array}$ & $\begin{array}{r}8.83 \\
11.13 \\
28.31 \\
28.09 \\
0.46 \\
15.18 \\
3.17 \\
3.01 \\
1.06 \\
0.33\end{array}$ & \begin{tabular}{|r|}
10.92 \\
0.71 \\
10.56 \\
30.39 \\
25.02 \\
$-\overline{-}$ \\
13.70 \\
2.51 \\
3.25 \\
0.91 \\
0.34
\end{tabular} & $\begin{array}{l}= \\
= \\
= \\
= \\
= \\
= \\
=\end{array}$ & $\begin{array}{r}11.83 \\
0.20 \\
10.57 \\
35.13 \\
23.36 \\
-\overline{11.46} \\
2.24 \\
2.55 \\
0.91 \\
0.33\end{array}$ & $\begin{array}{l}= \\
= \\
= \\
= \\
= \\
=\end{array}$ & $\begin{array}{r}11.59 \\
10.57 \\
35.13 \\
23.08 \\
0.81 \\
10.76 \\
2.77 \\
2.78 \\
0.91 \\
0.33\end{array}$ & $\begin{array}{r}13.87 \\
-\overline{10.57} \\
34.60 \\
23.64 \\
0.23 \\
10.54 \\
2.37 \\
2.78 \\
1.06 \\
0.27\end{array}$ & $\begin{array}{r}15.95 \\
- \\
16.14 \\
35.13 \\
18.08 \\
1.82 \\
6.44 \\
1.98 \\
3.47 \\
0.91 \\
0.23\end{array}$ \\
\hline$\left\{\begin{array}{l}o r \\
a b \\
a n\end{array}\right.$ & $\begin{array}{l}16 \\
45 \\
39\end{array}$ & $\begin{array}{l}42 \\
44\end{array}$ & 39 & $\begin{array}{l}42 \\
42\end{array}$ & $\begin{array}{l}16 \\
46 \\
38\end{array}$ & $\overline{-}$ & $\begin{array}{l}51 \\
34\end{array}$ & E & $\begin{array}{l}51 \\
34\end{array}$ & $\begin{array}{l}50 \\
35\end{array}$ & $\begin{array}{l}23 \\
51 \\
26\end{array}$ \\
\hline$\left\{\begin{array}{l}Q \\
\text { fo } \\
\text { fa }\end{array}\right.$ & $\begin{array}{l}44 \\
42 \\
14\end{array}$ & $\begin{array}{l}48 \\
37 \\
15\end{array}$ & $\begin{array}{l}40 \\
43 \\
11\end{array}$ & $\begin{array}{r}40 \\
9\end{array}$ & $\begin{array}{r}35 \\
7\end{array}$ & E & $\begin{array}{r}62 \\
32 \\
6\end{array}$ & E & $\begin{array}{r}29 \\
9\end{array}$ & $\begin{array}{r}27 \\
7\end{array}$ & $\begin{array}{r}75 \\
19 \\
6\end{array}$ \\
\hline$\left\{\begin{array}{l}\mathrm{MgO} \\
\text { FeO } \\
\text { Alkalies }\end{array}\right.$ & $\begin{array}{l}38 \\
32 \\
30\end{array}$ & $\begin{array}{l}38 \\
33 \\
29\end{array}$ & $\begin{array}{l}32 \\
32\end{array}$ & $\begin{array}{l}38 \\
30 \\
32\end{array}$ & $\begin{array}{l}35 \\
30 \\
35\end{array}$ & E & $\begin{array}{l}32 \\
38\end{array}$ & E & $\begin{array}{l}30 \\
40\end{array}$ & $\begin{array}{l}30 \\
41\end{array}$ & $\begin{array}{l}18 \\
33 \\
49\end{array}$ \\
\hline
\end{tabular}

* Determined as $\mathrm{Ni}, \mathrm{Cr}, \mathrm{V}, \mathrm{Cu}, \mathrm{Zn}$, and $\mathrm{Co}$ respectively and are not included in the total. Analyst, T. Katsura (Katsura, 1956).

** Including $\mathrm{CO}_{2} 0.11, \mathrm{BaO} 0.08, \mathrm{ZrO}_{2}$ trace.

1. Augite-olivine-bytownite andesitic basalt (Sd 25A), chilled phase, lowermost part on the south-eastern cliff, Otozan Flow. Analyst, T. Katsura.

2. Augite-olivine-bytownite andesitic basalt (Sd 283), chilled phase, 1 meter above the base, south-western cliff, Otozan Flow; about 380 meters west of No. 1. Analyst, M. Yamaguchi.

3. Augite-olivine-bytownite basaltic andesite (Sd 25), above No, 1, about 4 meters above the base. Analyst, M. Yamaguchi.

4. Augite-olivine-bytownite basaltic andesite ( $\mathrm{Sd} 26 \mathrm{~A}$ ), above No. 3 , about 10 meters above the base. Analyst, T. Katsura. 
5. Augite-bronzite-olivine-labradorite andesite ( $\mathrm{Sd} 26 \mathrm{D}$ ), above No. 4, about 12 meters above the base. Analyst, H. Matsumoto.

6. Augite-bearing olivine-bronzite andesite ( $\mathrm{Sd} 26 \mathrm{~F}$ ), above No. 5, about 17 meters above the base. Analyst, M. Yamaguchi.

7. Olivine-bronzite andesite ( $\mathrm{Sd} 27 \mathrm{~A}$ ), above No. 6, about 30 meters above the base. Analyst, T. Katsura.

7a. Olivine-bronzite andesite ( $\mathrm{Sd} 28$ ), above No. 7, about 40 meters above the base. Analyst, M. Yamaguchi.

8. Bronzite andesite ( $\mathrm{Sd} 30$ ), above No. 7a, about 65 meters above the base. Analyst, T. Katsura.

9. Bronzite andesite (Sd 29), about 15 meters east of No. 8, about 60 meters above the base. Analyst, T. Katsura. This rock contains abundant pegmatitoids.

10. Sanukite, Sanuki, Shikoku (sample from Krantz Co). Analyst, Wohlmann (Tröger, E. 1935).

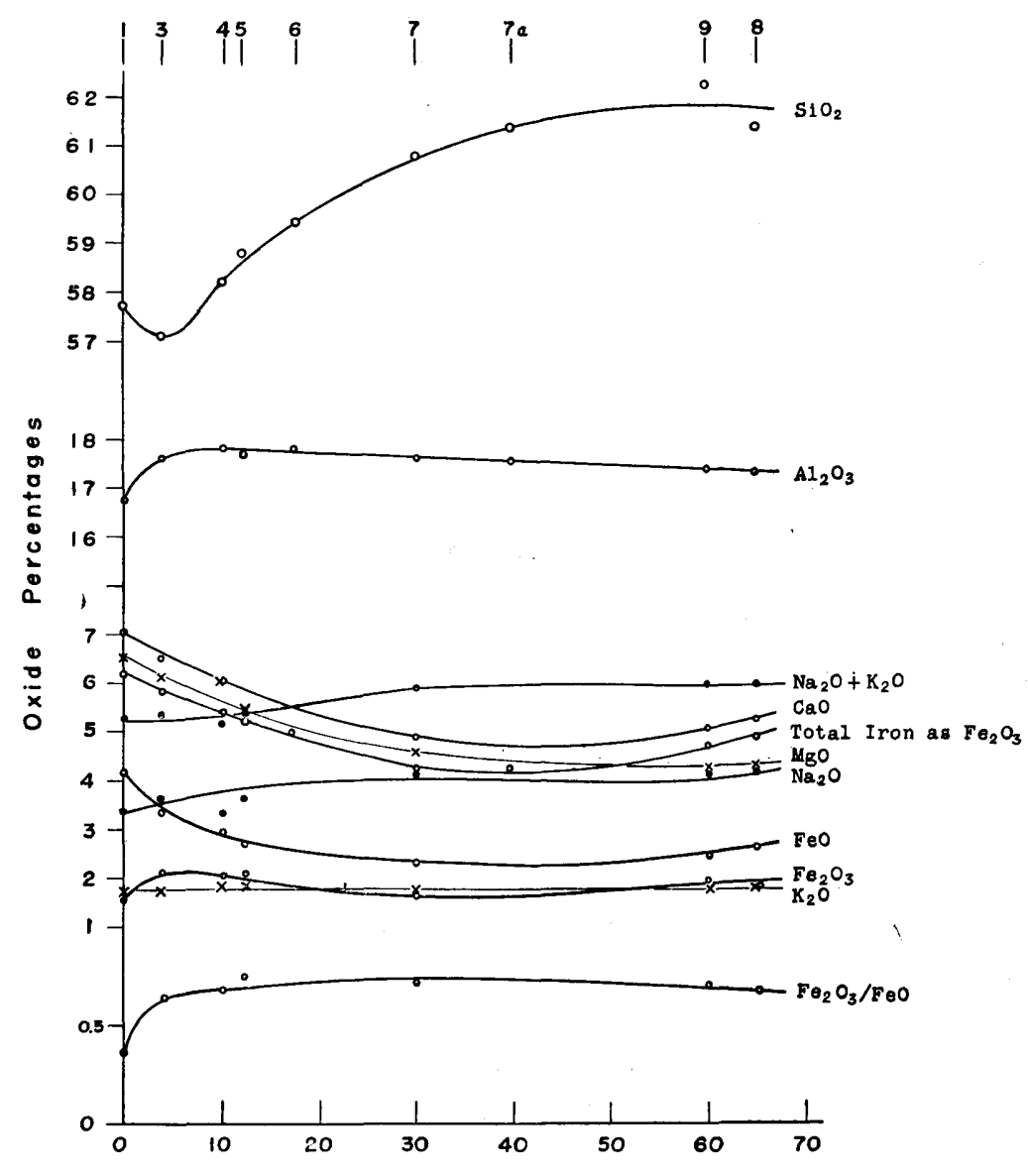

Height in meters above the lower contact

Fig. 13. Chemical variation against the height of the Otozan Flow. 


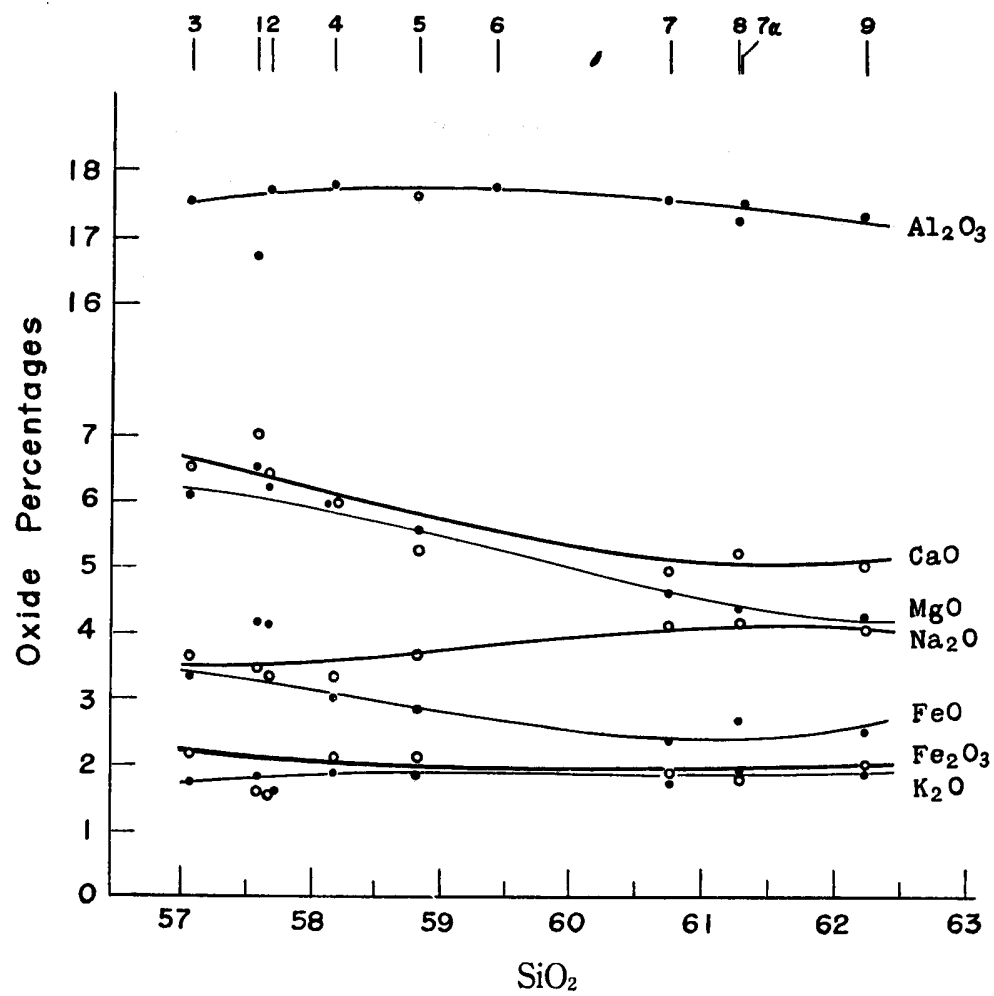

Fig. 14. Chemical variation against $\mathrm{SiO}_{2}$ of the Otozan Flow.

Table 8. Estimated groundmass composition of some rock types of the Otozan Flow.

\begin{tabular}{|c|c|c|c|c|c|}
\hline Sample No. & 1 & 2 & 4 & 7 & 8 \\
\hline $\begin{array}{l}\mathrm{SiO}_{2} \\
\mathrm{Al}_{2} \mathrm{O}_{3} \\
\mathrm{Fe}_{2} \mathrm{O}_{3} \\
\mathrm{FeO} \\
\mathrm{MgO} \\
\mathrm{CaO} \\
\mathrm{Na}_{2} \mathrm{O} \\
\mathrm{K}_{2} \mathrm{O} \\
\mathrm{H}_{2} \mathrm{O}(+) \\
\mathrm{TiO}_{2} \\
\mathrm{P}_{2} \mathrm{O}_{5} \\
\mathrm{MnO}\end{array}$ & $\begin{array}{r}59.9 \\
18.0 \\
1.7 \\
2.5 \\
3.8 \\
7.2 \\
3.6 \\
2.0 \\
0.1 \\
0.9 \\
0.2 \\
0.1\end{array}$ & $\begin{array}{r}59.3 \\
19.2 \\
1.7 \\
2.3 \\
4.2 \\
6.5 \\
3.6 \\
1.7 \\
0.7 \\
0.5 \\
0.2 \\
0.1\end{array}$ & $\begin{array}{r}59.3 \\
19.0 \\
2.2 \\
2.7 \\
4.1 \\
6.3 \\
3.5 \\
2.0 \\
0.1 \\
0.5 \\
0.2 \\
0.1\end{array}$ & $\begin{array}{r}61.7 \\
18.8 \\
1.8 \\
1.8 \\
3.0 \\
5.2 \\
4.4 \\
1.9 \\
0.6 \\
0.5 \\
0.2 \\
0.1\end{array}$ & $\begin{array}{r}61.6 \\
18.6 \\
2.0 \\
1.8 \\
2.5 \\
5.6 \\
4.5 \\
1.9 \\
0.7 \\
0.5 \\
0.2 \\
0.1\end{array}$ \\
\hline & 100.0 & 100.0 & 100.0 & 100.0 & 100.0 \\
\hline $\begin{array}{l}\text { Q } \\
\text { C } \\
\text { or } \\
a b \\
\text { an } \\
\text { wo } \\
\text { en } \\
\text { fs } \\
\text { mt } \\
\text { il } \\
\text { ap }\end{array}$ & $\begin{array}{r}11.5 \\
11.7 \\
30.4 \\
27.0 \\
3.4 \\
9.5 \\
1.9 \\
2.5 \\
1.7 \\
0.3\end{array}$ & $\begin{array}{r}11.2 \\
10.0 \\
30.4 \\
31.1 \\
0.1 \\
10.4 \\
2.1 \\
2.6 \\
0.9 \\
0.3\end{array}$ & $\begin{array}{r}11.2 \\
11.7 \\
29.3 \\
30.3 \\
0.1 \\
10.2 \\
2.5 \\
3.3 \\
0.9 \\
0.3\end{array}$ & $\begin{array}{r}13.1 \\
0.3 \\
11.1 \\
37.2 \\
25.0 \\
\\
7.5 \\
1.2 \\
2.6 \\
0.9 \\
0.3\end{array}$ & $\begin{array}{r}12.7 \\
11.1 \\
38.3 \\
24.7 \\
0.9 \\
6.3 \\
0.9 \\
3.0 \\
0.9 \\
0.3\end{array}$ \\
\hline
\end{tabular}




\begin{tabular}{|c|c|c|c|c|c|}
\hline$\left\{\begin{array}{l}o r \\
\mathrm{ab} \\
\mathrm{an}\end{array}\right.$ & $\begin{array}{l}17 \\
44 \\
39\end{array}$ & $\begin{array}{l}14 \\
43 \\
43\end{array}$ & $\begin{array}{l}16 \\
41 \\
43\end{array}$ & $\begin{array}{l}15 \\
51 \\
34\end{array}$ & $\begin{array}{l}15 \\
52 \\
33\end{array}$ \\
\hline$\left\{\begin{array}{l}\mathrm{Q} \\
\text { fo } \\
\mathrm{fa}\end{array}\right.$ & $\begin{array}{r}65 \\
29 \\
6\end{array}$ & $\begin{array}{r}62 \\
31 \\
7\end{array}$ & $\begin{array}{r}62 \\
30 \\
8\end{array}$ & $\begin{array}{r}72 \\
24 \\
4\end{array}$ & $\begin{array}{r}74 \\
22 \\
4\end{array}$ \\
\hline$\left\{\begin{array}{l}\mathrm{MgO} \\
\text { FeO } \\
\text { Alkalies }\end{array}\right.$ & $\begin{array}{l}28 \\
30 \\
42\end{array}$ & $\begin{array}{l}32 \\
28 \\
40\end{array}$ & $\begin{array}{l}29 \\
32 \\
39\end{array}$ & $\begin{array}{l}23 \\
27 \\
50\end{array}$ & $\begin{array}{l}20 \\
29 \\
51\end{array}$ \\
\hline
\end{tabular}

\section{Summary}

The Upper Miocene Otozan Flow (about 20-80 meters thick) on Shodo-shima Island in the Seto-uchi Inland Sea, Southwest Japan, is remarkably layered, consisting of four rock types: from the base upwards, augite-olivine-bytownite andesitic basalt, augite-bearing olivine-bronzite andesite, olivine-bronzite andesite and bronzite andesite, which are perfectly gradational into each other. These various facies of the Flow are included in the "sanukitoids" of the Seto-uchi region. Structural, microscopical and chemical studies show that the flow is of the composite type, differentiated not in situ but prior to its extrusion.

The abundance of bronzite-hypersthene and the presence of potash-oligoclase in the rocks reflect in their chemical composition: abnormally high contents of magnesia and alkalies for calc-alkaline volcanic rocks. In particular, the dispersed xenocrysts of plagioclase and quartz, and the sporadic inclusions of abnormal orthopyroxene and of bronzite-biotite-alkali feldspar aggregate may suggest that the contamination of an olivine basaltic magma at depth partook the formation of the lavas dealt with in this paper. The petrogenic discussion will be given in the near future.

\section{Acknowledgments}

I wish to express my gratitude to the late Professor K. Sugr who recommended me to do this study; to Professor T. Tomita and Assistant Professor S. Taneda of our Department, and to Dr. H. L. Foster of the U.S. Geological Survey then in Tokyo, for their valuable advice during my study and preparation of this paper; in particular, I owe much to Professor T. Tomita for his kindness in sparing his time and effort to offer helpful criticism and correct my English writing. I am also greatly indebted to Dr. T. Katsura of the Chemical Laboratory, Tokyo Institute of Technology, and to Mr. H. Matsumoto of Kumamoto University for their kind help with chemical analyses. For financial help apprecation is expressed to the Grant in Aid for Scientific Researches from the Ministry of Education, Japan. 


\section{References}

Bailey, E. B., Thomas, H. H. et al. (1924) Tertiary and post-Tertiary geology of Mull, Loch Aline and Oban: Mem. Geol. Surv. Scotland, 445 pp.

Barth, Tom. F. W. (1930) Pacificite, an anemousite basalt: Jour. Washington Acad. Sci., 20, $60-68$.

(1952) Theoretical Petrology, (New York), 387 pp.

Hess, H. H. (1949) Chemical composition and optical properties of common clinopyroxenes, I: Am. Mineral., 34, 621-666.

Katsura, T. (1956) Geochemical investigation of volcanoes in Japan: 34, Vanadium content of volcanic rocks in western part from the Fuji volcanic zone; 37, Nickel content of volcanic rocks in western and northern part from the Fuji volcanic zone; 39, Cobalt content of volcanic rocks in western and northern part from the Fuji volcanic zone; 40, Copper and zinc contents of volcanic rocks in Japan: Jour. Chem. Soc. Japan, 77, $1076-1081$; 1368-1374; 1553-1558; 1558-1562 (in Japanese).

Koтo, B. (1916) On the volcanoes of Japan, V: Jour. Geol. Soc. Tokyo, 23, 95-127 (116).

KozU, S., and YAGI, K. (1941) Chemical studies of garnet and its mother rock from Amataki : Jour. Jap. Assoc. Mineral. Petrol. Econ. Geol., 26, 73-121 (in Japanese).

Kuno, H. (1954) Study of orthopyroxene from volcanic rocks: Am. Mineral., 39, 30-46.

MAcdonald, G. A. (1942) Potash-oligoclase in Hawaiian lavas: Am. Mineral., 27, 793-800.

Matumoto, Tadaiti (1937) On the so-called Aso volcanic chain: Report of the Japanese Assocation for Advancement of Science, 12, 182-184 (in Japanese).

Matsumoto, Takashi (1950) Some aspects of contamination in the volcanic rocks of Setouchi volcanic zone: Jour. Geol. Soc. Japan, 56, 529-535 (in Japanese).

Morimoto, R. (1944) Mode of occurrence of garnet at Nijo volcano; Microscopic observation of garnet-bearing xenoliths: Jour. Jap. Assoc. Mineral. Petrol. Econ. Geol., 32, 218 -225 (in Japanese).

OHMoRI, K. (1942) Studies of garnet in andesites forming the volcano Nijo-san: Jour. Jap. Assoc. Mineral. Petrol. Econ. Geol., 27, 27-58; 69-87 (in Japanese).

PoldervaArT, A. (1950) Correlation of physical properties and chemical composition in the plagioclase, olivine, and orthopyroxene series: Am. Mineral., 35, 1067-1079.

SAto, M. (1936) 1:75,000 geological sheet map and explanatory text of the Takamatsu: Imp. Geol. Survey, Japan (in Japanese with English abstract) 56 pp.

(1938) 1:75,000 geological sheet map and explanatory text of the Saidaiji: Imp. Geol. Survey, Japan (in Japanese with English abstract) $54 \mathrm{pp}$.

SugI, K. (1938) On the sanukites at the environs of Takamatsu, Sikoku, with special reference to the xenocrysts found in rocks: Bull. Volcan. Soc. Japan, 4, 17-33 (in Japanese).

Takeuchi, T. (1941) Studies of garnet and its country rock from Amataki: Jour. Jap. Assoc. Mineral. Petrol. Econ. Geol., 26, 33-60 (in Japanese).

Tomita, T. (1931) Geological and petrological study of Dogo, Oki, Parts 11 and 12: Jour. Geol. Soc. Japan, 38, 211; 422; etc. (in Japanese).

(1935) On the chemical composition of the Cenozoic alkaline suite of the Circum Japan Sea region: Jour. Shanghai Sci. Inst., Sec. 2, 1, 272-306.

(1948). Cenozoic volcanic geology of North China, Part 2: Kagaku Jiho, March, 9193 (in Chinese).

(1951) Types of magmatic evolution: Kyushu Univ. Fac. Sci. Reports, Geol., 3, 77104 (in Japanese).

TRögER, E. (1953) Quantitative Daten einiger magmatischer Gesteine: Min. Petrogr. Mitt., 46, 153-173.

Weinschenk, E. (1891) Beiträge zur Petrographie Japans: Neus Jahrb., B. B., VII, 150.

Wilcox, R. E. (1954) Petrology of Paricutin volcano, Mexico: U. S. Geol. Survey Bull., 965-c, 281-353.

Yoshizawa, H. (1930) Preliminary study of Nijo volcano: Chi-kyu (The Globe), 14, 344-362 (in Japanese). 
M. YAMAGUCHI

Petrography of the Otozan Flow on Shodo-shima Island Seto-uchi Inland Sea, Japan

Plates 


\section{Plate 36}

Fig. 1. Augite-olivine-bytownite andesitic basalt (No. 1: Sd 25A), a chilled phase at the base of the Otozan Flow.

Fig. 2. Augite-olivine-bytowinte andesitic basalt (No. $3: \mathrm{Sd} 25$ ), 4 meters above the base.

Fig. 3. Augite-olivine basaltic andesite (No. 4:Sd 26A), 10 meters above the base.

Fig. 4. Augite bearing olivine-bronzite andesite (No. 5:Sd 26D), 12 meters above the base.

\section{Plate 37}

Fig. 5. Augite-bearing olivine-bronzite andesite (No. 6:Sd 26F), 17 meters above the base.

Fig. 6. Olivine-bronzite andesite (No. $7: \mathrm{Sd} 27 \mathrm{~A}$ ), about 30 meters above the base.

Fig. 7. Bronzite andesite (No. 8:Sd 30), about 65 meters above the base.

Fig. 8. Corroded quartz xenocryst surrounded by a corona consisting of augite, biotite and glass in Augite-olivine basaltic andesite (Sd 25C).

\section{Plate 38}

Fig. 9. A: General features of the highly crystalline groundmass of bronzite andesite. Phase contrast illumination (Sd 29B). P : potash-oligoclase, $\mathrm{Cr}$ : cristobalite.

B: Potash-oligoclase $(\mathrm{P})$ under high-power microscope. Hy: hypersthene, $\mathrm{Cr}$ : cristobalite.

C: Abundant inclusions of slender apatite in potash-oligoclase (P). parallel Nicols (Sd 28A).

D: Potash-oligoclase (P). crossed Nicols (Sd 28A).

\section{Plate 39}

Fig. 10. Potash-oligoclase cut normal to $Z$ (Sd 29).
A : open Nicols.
B : crossed Nicols.

Fig. 11. Abnormal bronzite-hypersthene xenocryst in bronzite andesite ( $\mathrm{Sd} 28 \mathrm{~A}$ ).

Fig. 12. Aggregate of abnormal bronzite xenocryst in bronzite andesite ( $\mathrm{Sd} \mathrm{835).}$

\section{Plate 40}

Fig. 13. Plagioclase xenocryst in bronzite andesite (Sd 279).

Fig. 14. Xenocrystic quartz (Q), aggregate of grains, surrounded by augite in bronzite andesite (Sd 27F).

Fig. 15. Advanced stage of the transformation phase of siliceous xenolith represented by good development of bronzite (br), biotite (bi), feldspathic minerals, and tridymite (tr) (Sd 831).

Fig. 16. Advanced stage of the transformation phase of xenolith represented by good development of bronzite (br), a few augite (au), and glass (gl) (Sd 280).

Photos by Yamaguchi 

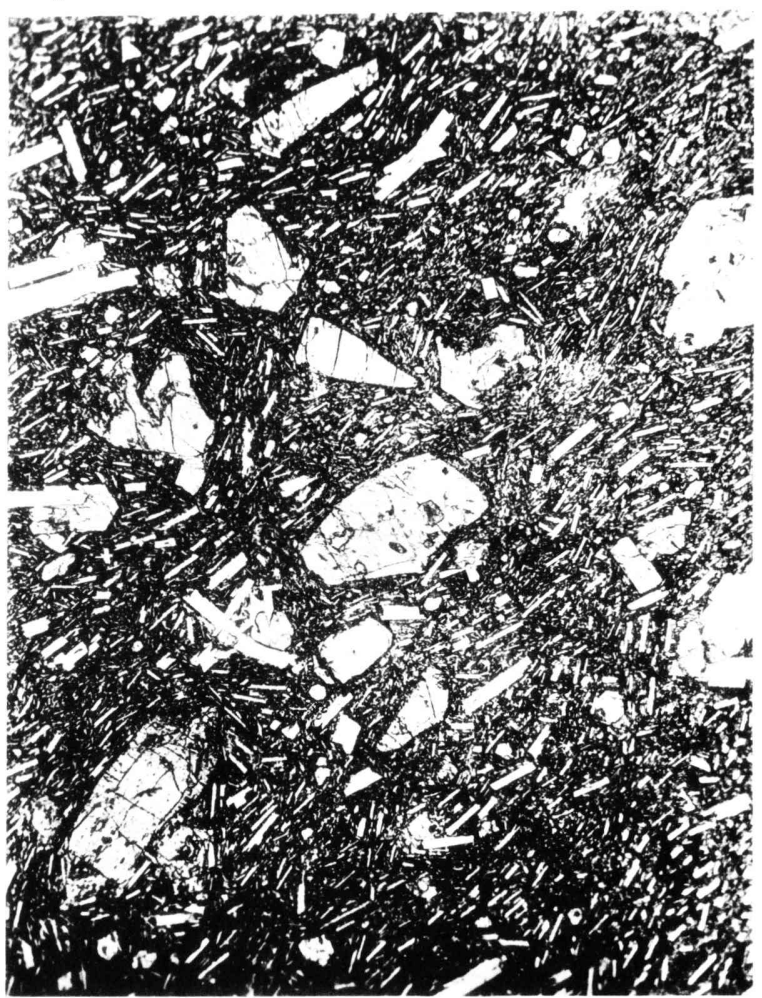

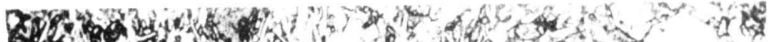

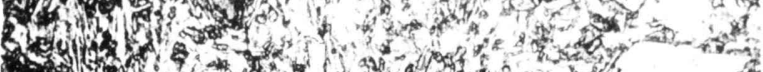

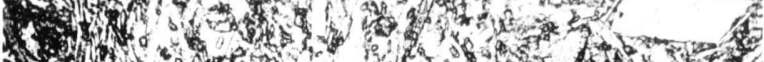
(1) 150 .

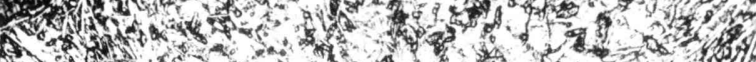

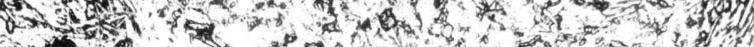

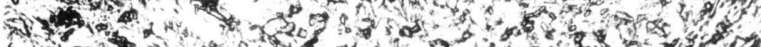

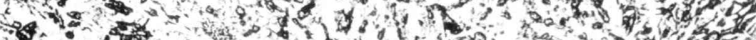

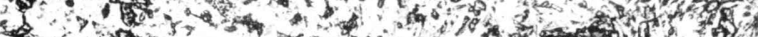

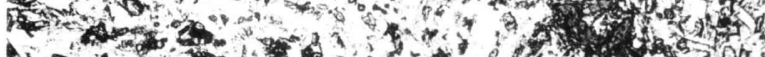

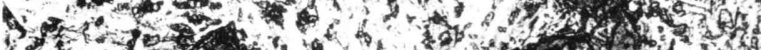

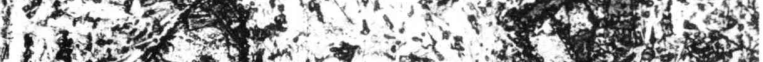

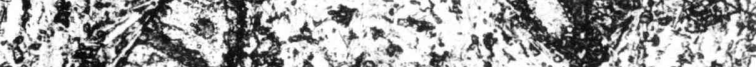

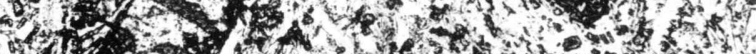

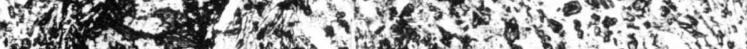

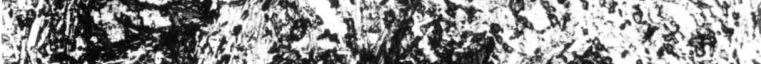

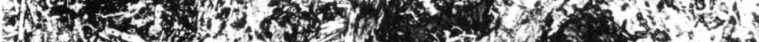

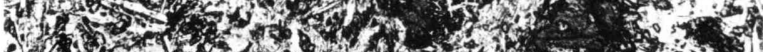
G.

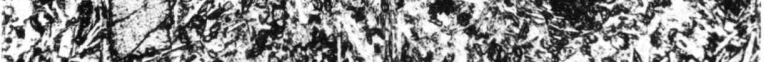

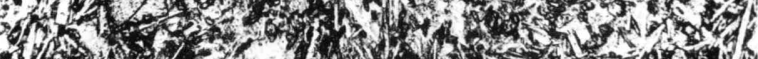

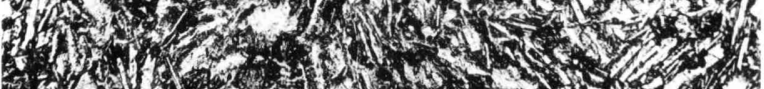

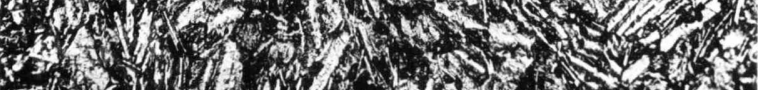

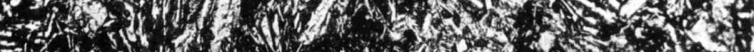

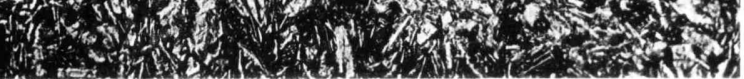

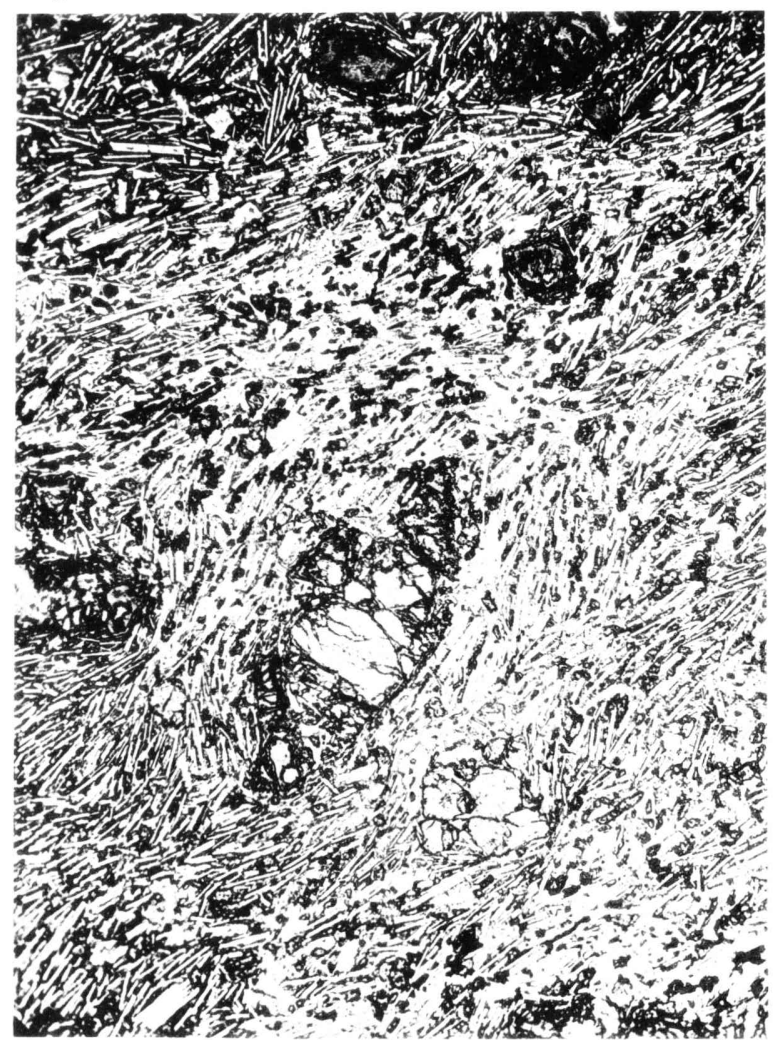

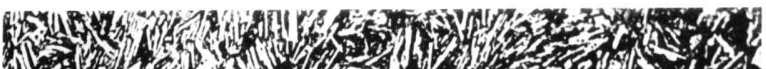

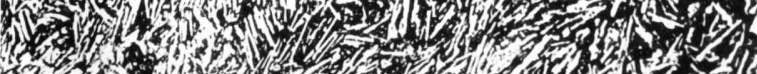

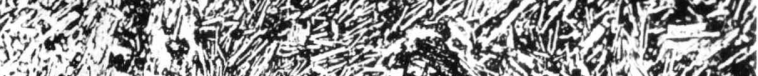

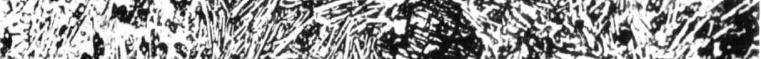

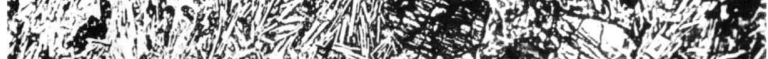
4.

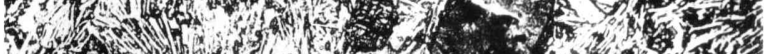

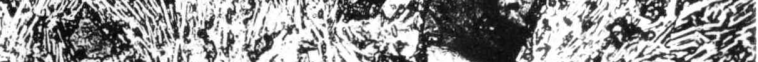
r.t

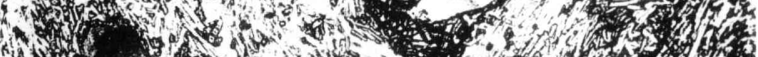

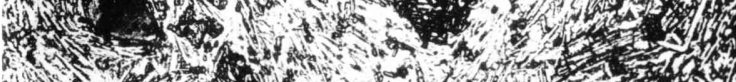

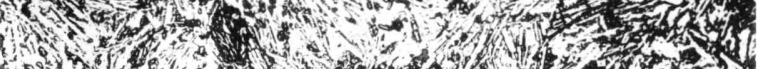

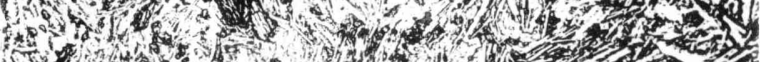

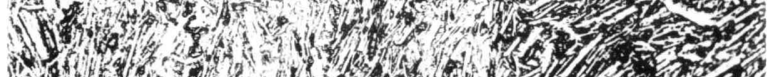

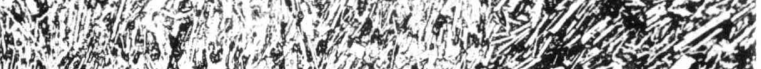
H.

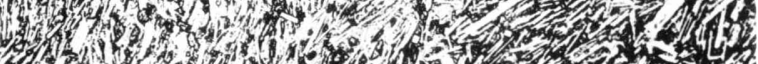
4. 71 .

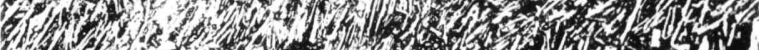

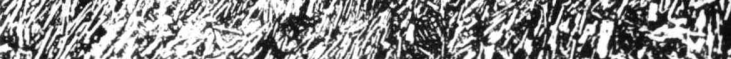

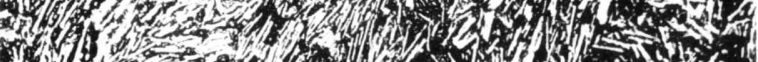
7.

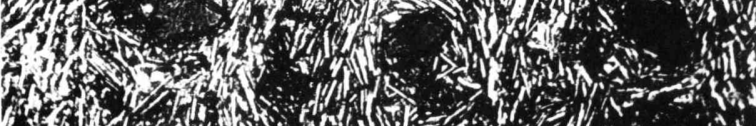

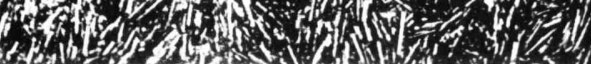




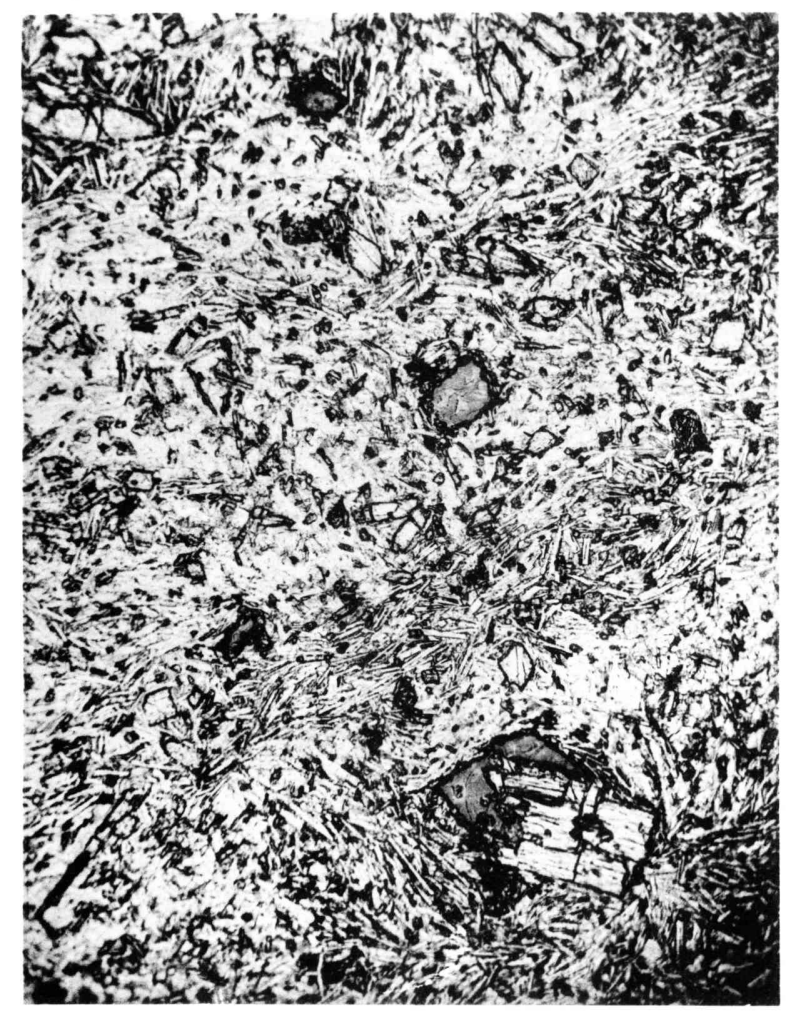

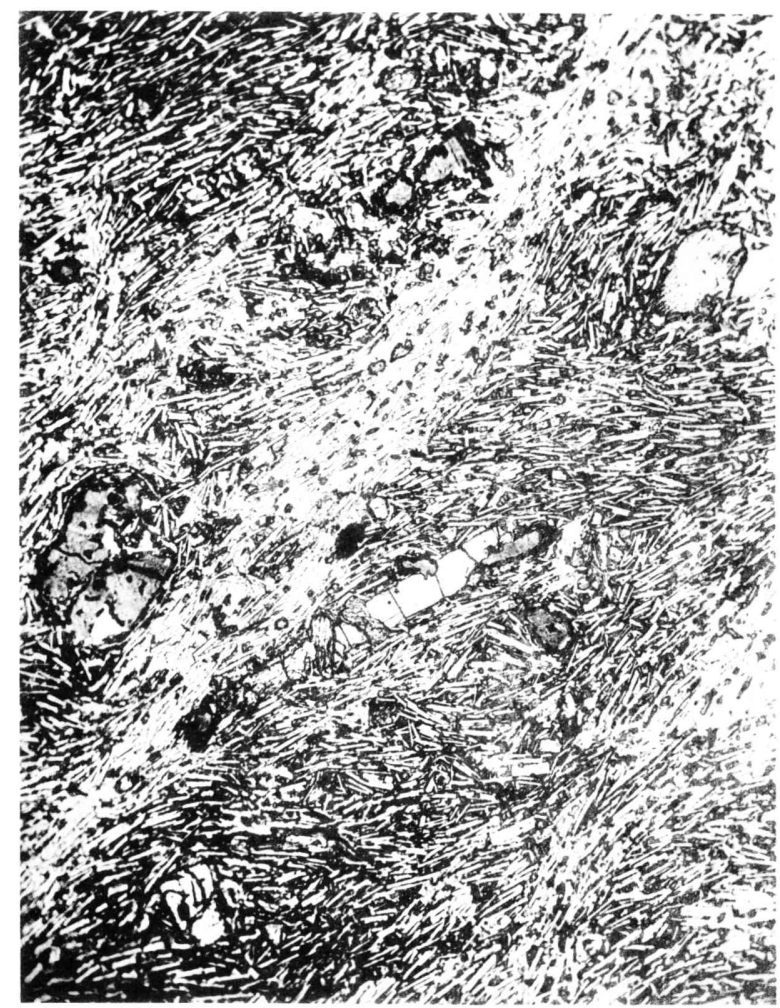

$1 \mathrm{~mm}$

2.

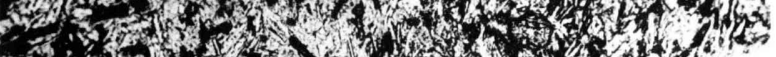

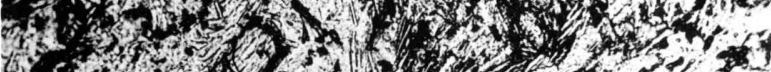

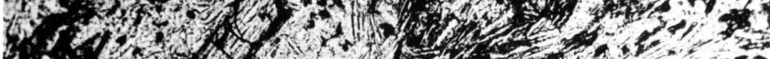

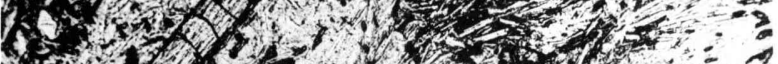
s.t.

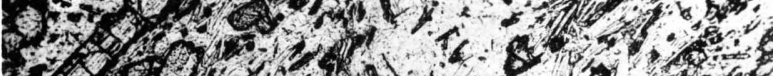

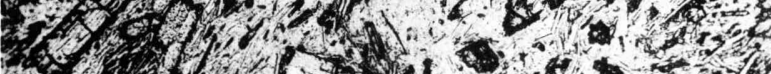

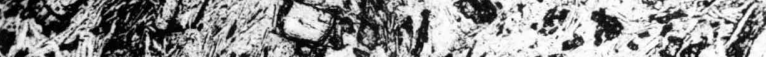

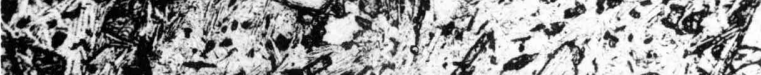

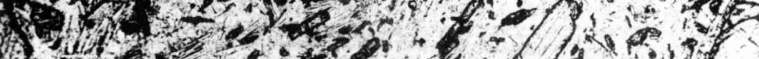

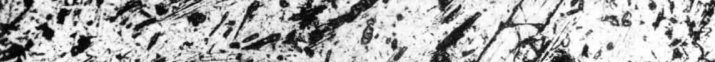

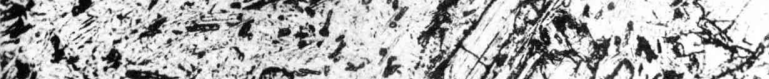

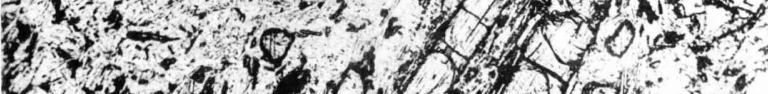

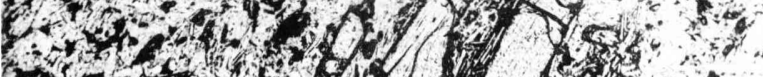
1.5.

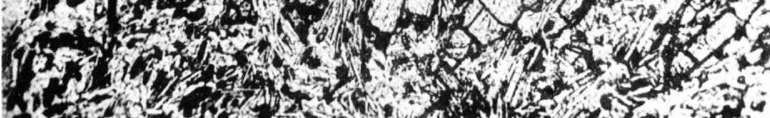

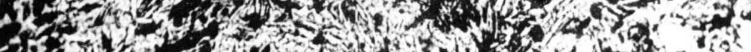
15)

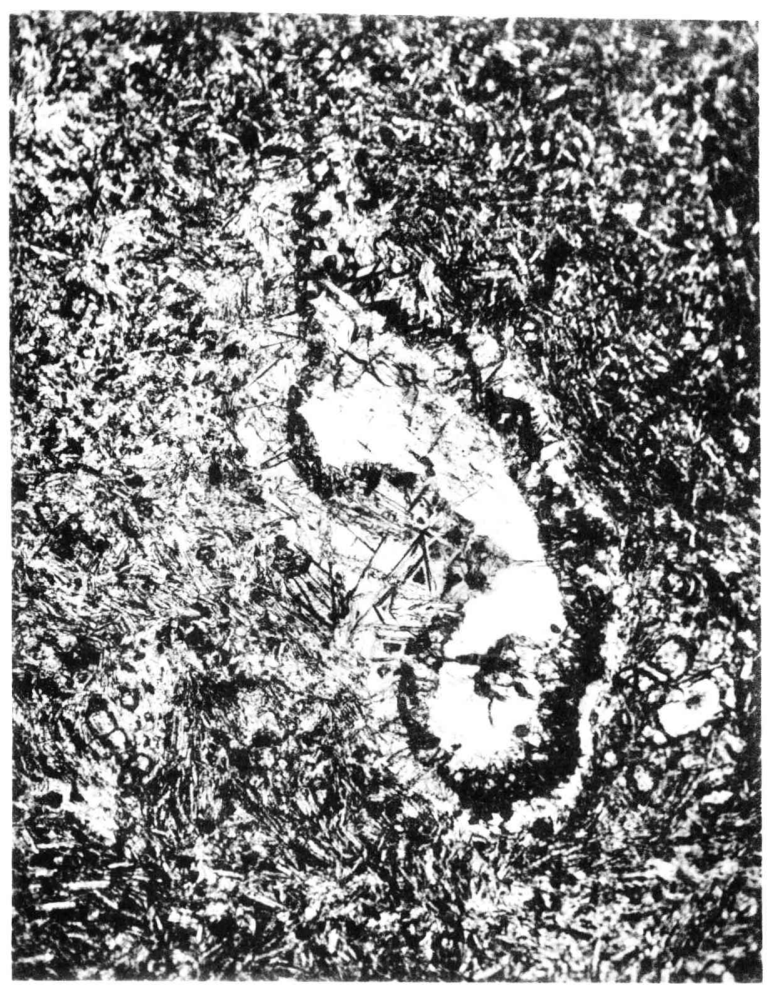


$9 \mathrm{~A}$ area of $9 \mathrm{~B}$

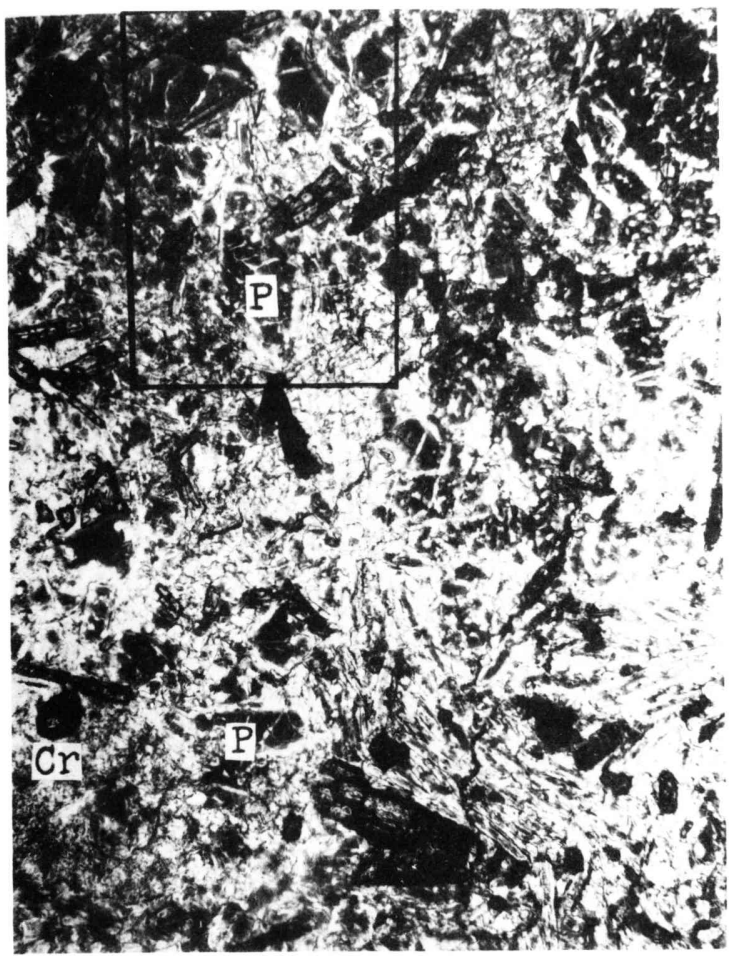

$9 \mathrm{~B}$

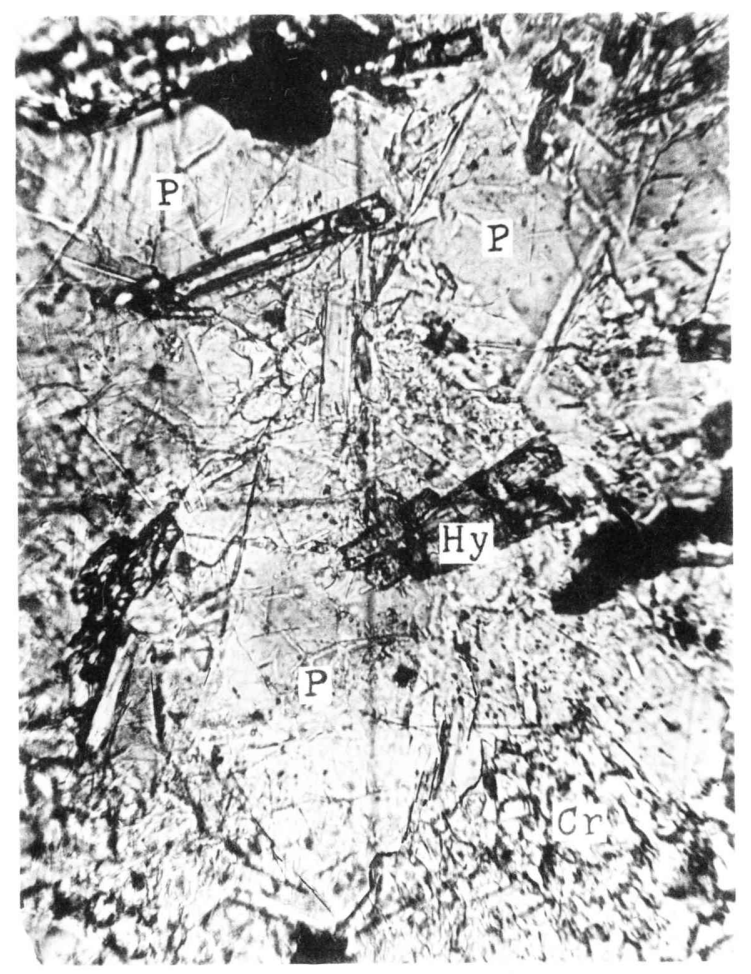

$100 \mu$

9D

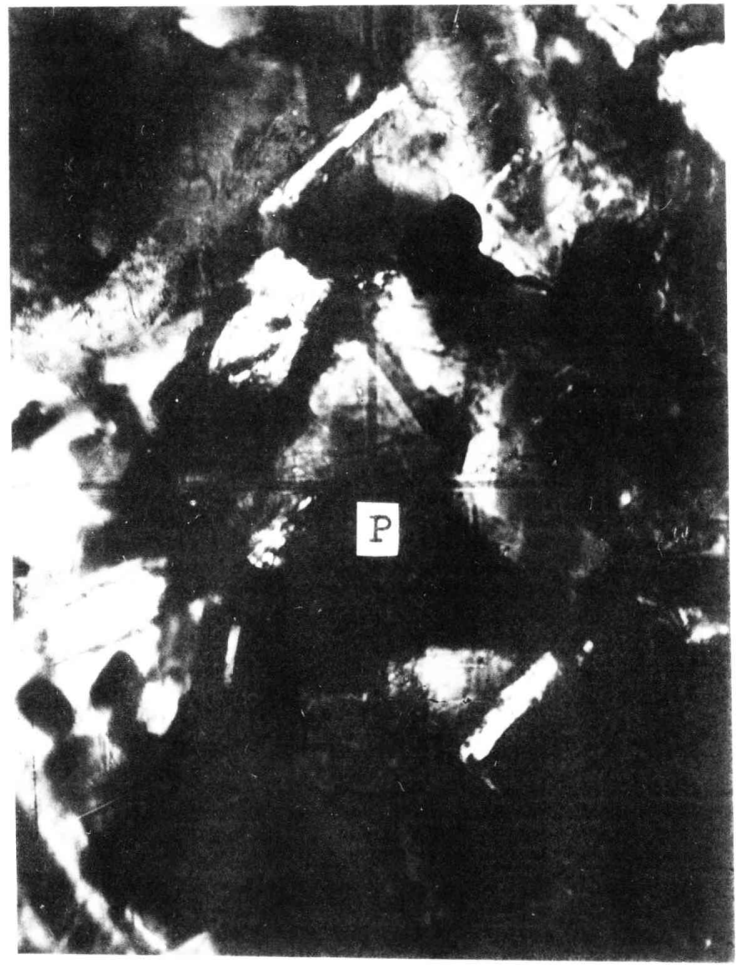


$10 \mathrm{~A}$

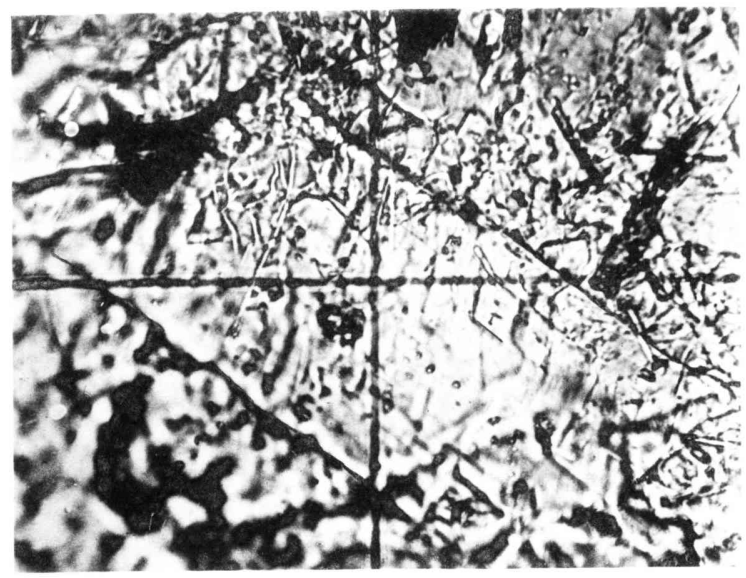

$10 \mathrm{~B}$

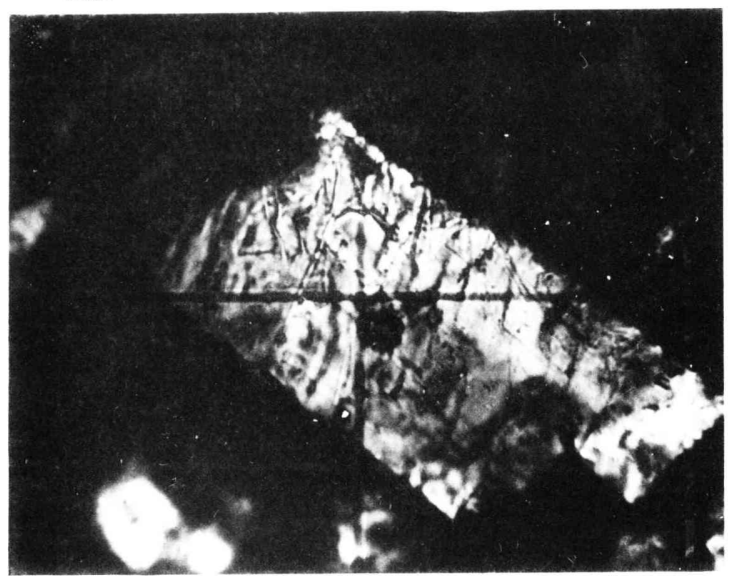

$100 \mu$

12

11

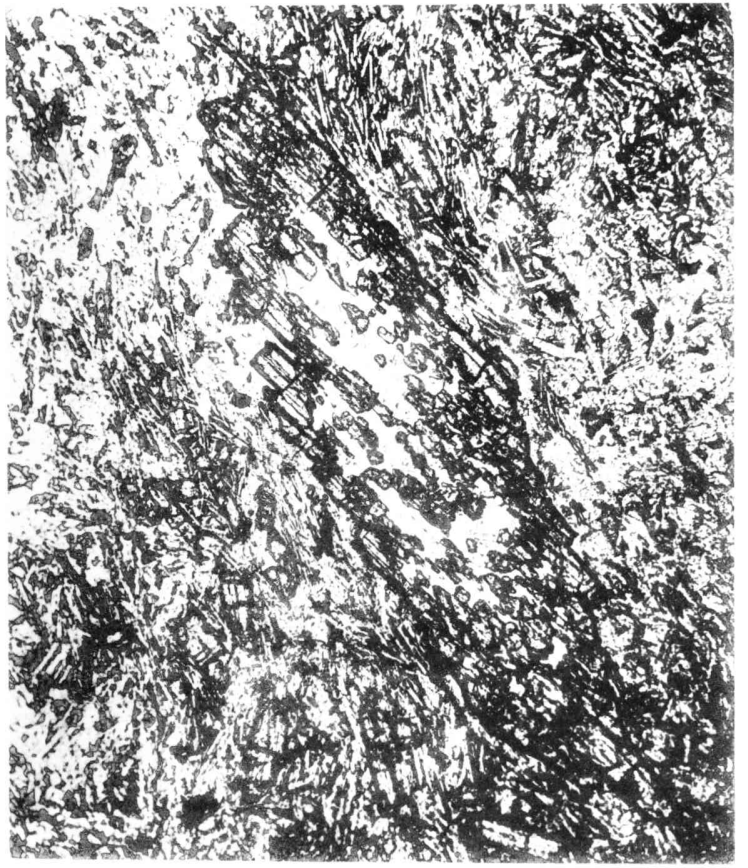

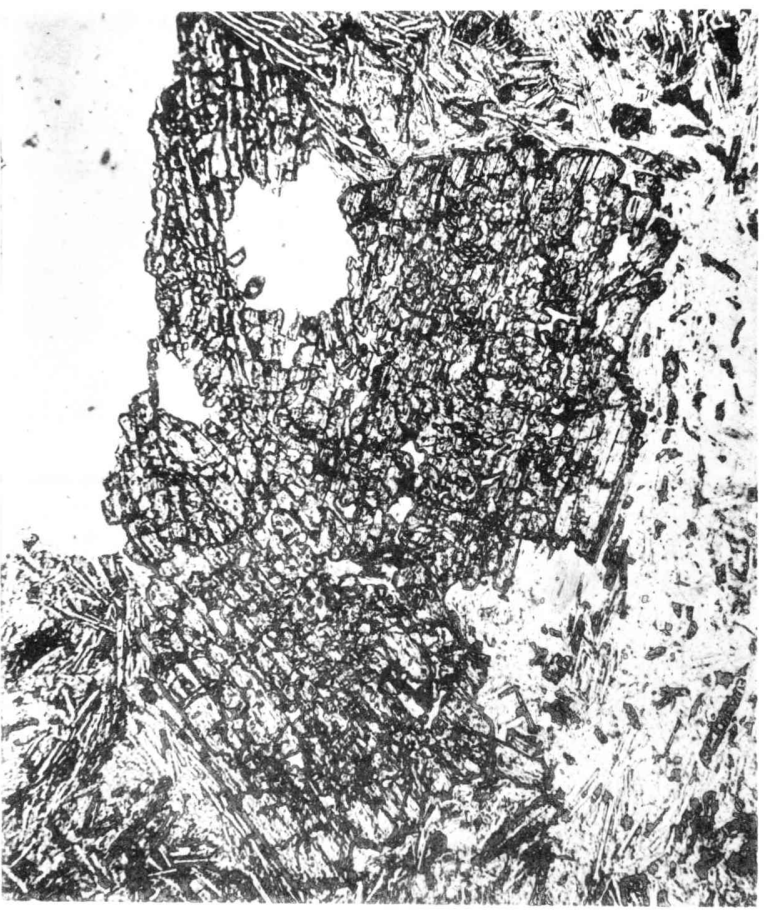

$0.5 \mathrm{~mm}$

M. YAmaguchi: Petrography of the Otozan Flow 
13

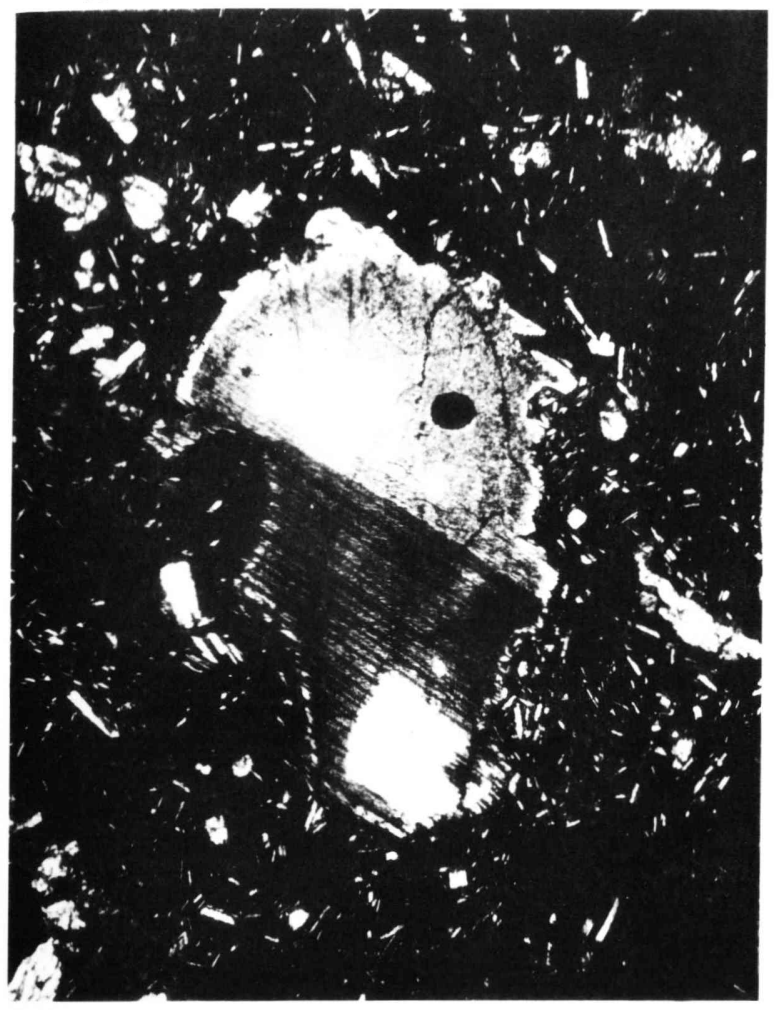

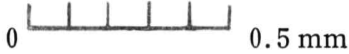

15

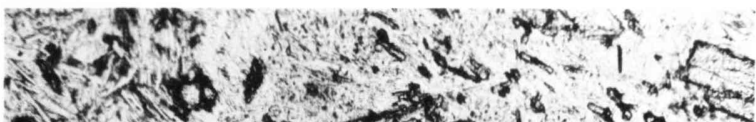

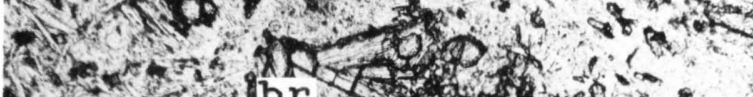

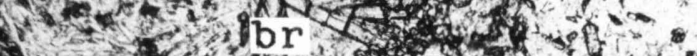

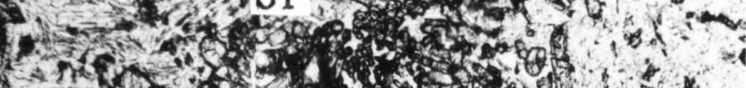

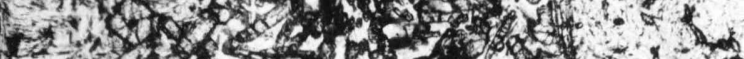

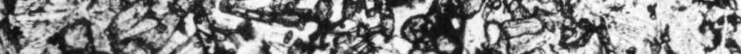

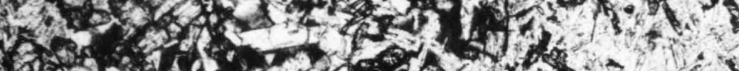

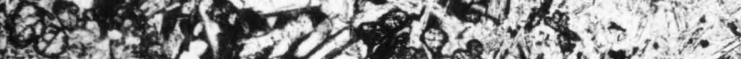

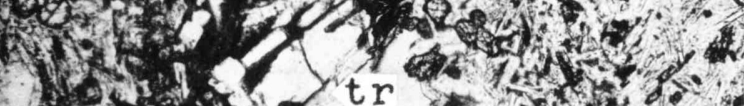

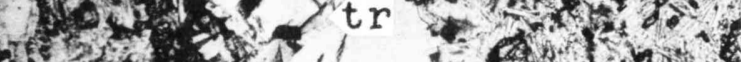

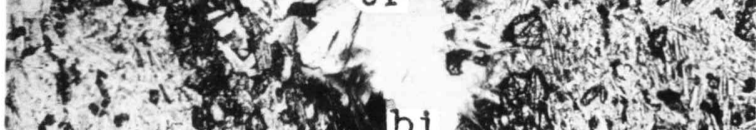

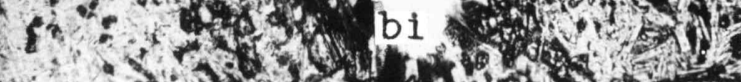

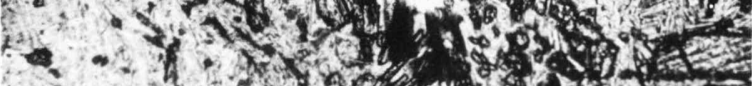

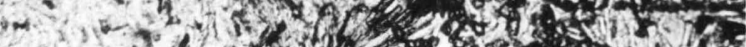

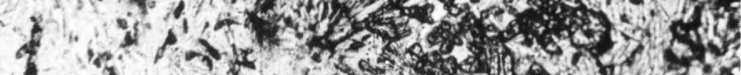

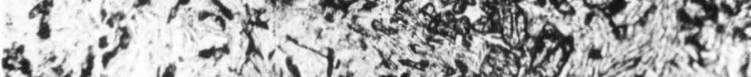

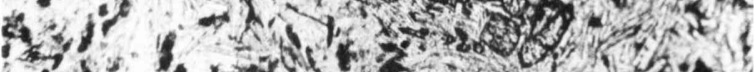

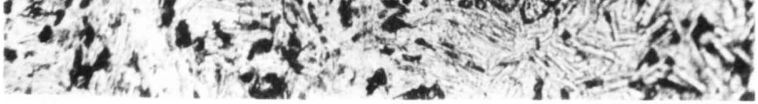

\section{4}

- 1 Ifos

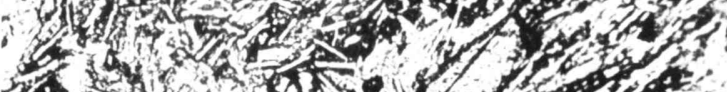
行

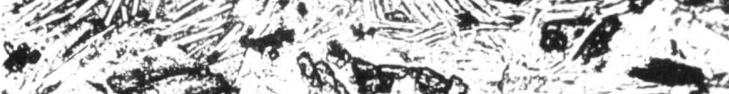

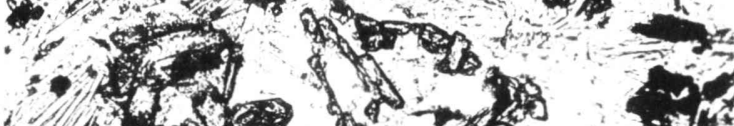

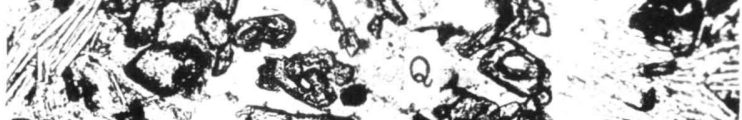

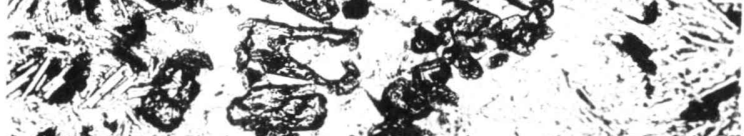

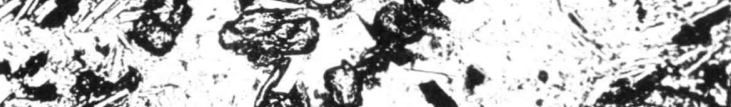

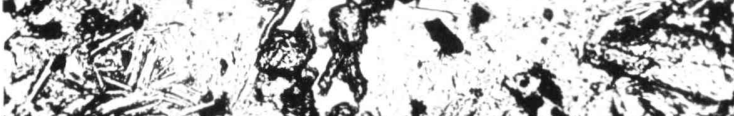

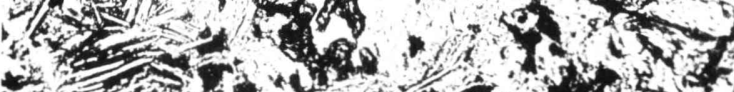

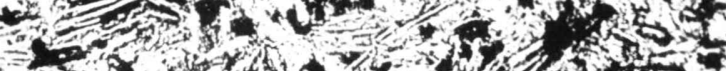

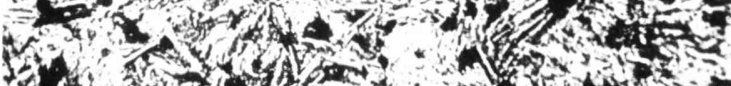

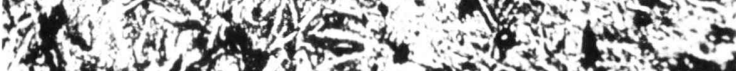

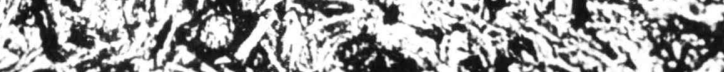

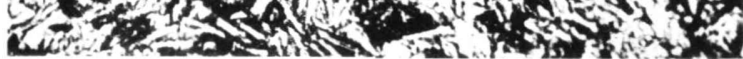

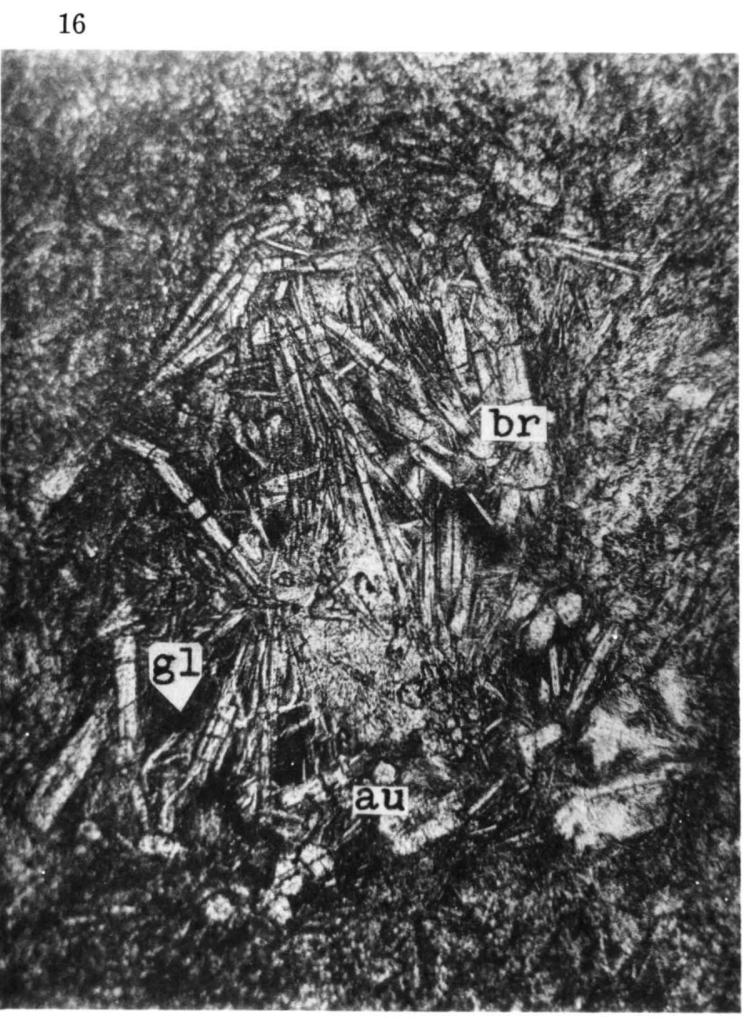

